\title{
A Bibliometric Review on Decision Approaches for Clean Energy Systems under Uncertainty
}

\author{
Alok K. Pandey ${ }^{1}$, R. Krishankumar ${ }^{2}$, Dragan Pamucar ${ }^{3}{ }^{-1}$, Fausto Cavallaro ${ }^{4, *(\mathbb{D}}$, Abbas Mardani ${ }^{5}$, Samarjit Kar ${ }^{1}$ \\ and K. S. Ravichandran ${ }^{6}$ \\ 1 Department of Mathematics, NIT Durgapur, Durgapur 713209, WB, India; \\ akp.20p10218@mtech.nitdgp.ac.in (A.K.P.); samarjit.kar@maths.nitdgp.ac.in (S.K.) \\ 2 Department of Computer Science and Engineering, Amrita School of Engineering, Amrita Vishwa \\ Vidyapeetham, Coimbatore 641105, TN, India; r_krishankumar@cb.amrita.edu \\ 3 Department of Logistics, Military Academy University of Belgrade, 11000 Belgrade, Serbia; \\ dragan.pamucar@va.mod.gov.rs \\ 4 Department of Economics, University of Molise, 86100 Campobasso, Italy \\ 5 Muma College of Business, University of South Florida, Tampa, FL 33620, USA; \\ abbas.mardani.edu@gmail.com \\ 6 Rajiv Gandhi National Institute of Youth Development, Sriperumbudur 602105, TN, India; \\ ksravi@rgniyd.gov.in \\ * Correspondence: cavallaro@unimol.it
}

check for

updates

Citation: Pandey, A.K.;

Krishankumar, R.; Pamucar, D.;

Cavallaro, F.; Mardani, A.; Kar, S.;

Ravichandran, K.S. A Bibliometric

Review on Decision Approaches for

Clean Energy Systems under

Uncertainty. Energies 2021, 14, 6824.

https://doi.org/10.3390/en14206824

Academic Editors: João

Fernando Pereira Gomes and

Abu-Siada Ahmed

Received: 15 July 2021

Accepted: 14 October 2021

Published: 19 October 202

Publisher's Note: MDPI stays neutral with regard to jurisdictional claims in published maps and institutional affiliations.

Copyright: (c) 2021 by the authors. Licensee MDPI, Basel, Switzerland. This article is an open access article distributed under the terms and conditions of the Creative Commons Attribution (CC BY) license (https:// creativecommons.org/licenses/by/ $4.0 /)$.
Abstract: This paper aims to provide a bibliometric review on the diverse decision approaches in uncertain contexts for clean energy system (CES) assessment. A total of 126 publications are analyzed. Previous reviews on CES have discussed several research questions on the decision methods and the applicability of evaluating CES, along with the factors associated with CESs. In the present study, we focus on the bibliometric aspect that attempts to address questions related to the prominence of authors, countries/regions that focus on the current theme, impact of journals, importance of articles in the research community, and so on. The window considered for the study is from 2018 to 2021, with the motive to extend the review process from the preceding works. A review model is presented to address the questions based on the literature evidence. The results infer that CESs are the most viable mode for sustainable development, and the use of decision approaches is apt for the assessment of CESs.

Keywords: bibliometric study; clean energy system; decision approaches; uncertainty

\section{Introduction}

Clean energy is a desirable option for satisfying the energy demand of the public, as the conventional forms create environmental issues and play a significant role in climate change [1]. To combat the challenge, aggressive measures are taken worldwide to encourage clean energy generation and usage. Recently, in the Paris Accord, countries had a detailed discussion regarding climate change and the possible ways to reduce the carbon footprint. Countries are committed to achieving a considerable reduction in the carbon trace by 2025 [2,3]. The work in [4] reviewed the different decision methods used in clean energy evaluation and proved the power of decision methods for applications involving competing criteria for rating/evaluation. Developing countries, such as India, seek high energy to satisfy the demand of the people, and by 2040-2050, the transformation to CES will become highly essential [5]. The US Energy Information Administration (www.eia.gov, dated 5 April 2021) reported that almost 74\% of greenhouse gas emissions are from burning fossil fuels in the US. Further reports indicate that in 2018, air pollution accounted for the cost of $3.3 \%$ of global GDP, which was primarily from fossil fuels. It was found that from 1990 to 2013 , the total primary energy supply grew to $54.4 \%$, of which only $13.8 \%$ was from CESs [4]. 
These claims drive researchers to put forth computational models to assess CESs and issues associated with them. From the works presented in [6-8], it is clear that decision approaches are very suitable for assessing CESs, as the criteria are conflicting and competing with one another. Furthermore, fuzzy sets can model uncertainty effectively in such decision problems. Earlier literature reviews related to CESs [8-11] provide the following inferences:

- Fuzzy sets are key concepts that are used for modeling uncertainty in the decision process associated with CES.

- Most of the literature studies obtain data as rating information in the Likert-scale form and transform them into fuzzy values to generate decisions.

- The criteria for such applications are competing and conflicting with one another, and the estimation of their relative importance is considered a crucial stage in the existing framework.

- Utility function-based formulation and distance measure-based formulation are popular in ranking CESs and their associated options.

- Earlier literature reviews have also claimed that the assessment of CESs using multicriteria decision making (MCDM) will grow due to the nature of the problem and the efficacy of the method.

These inferences motivate the current bibliometric literature review. Besides, the existing review articles have paid little attention to the bibliometric theme of review in the CES assessment field. Also, a review of CES-related works after 2018 needs to be well explored. In this paper, we attempt to exploit this direction to give readers clarity of the following review questions (RQs). It must be clearly understood that these RQs are answered based on the data collected and presented in this study, which consist of 134 articles, and so the results are pertaining to these 1 papers that authors attempt to review.

- Which countries prominently contributed to CES-related research based on the data collection by authors?

- Who are the prominent first authors in the CES assessment field based on the collected articles from 2018 to 2021 ?

- Which publisher and journal(s) dominate and attract articles in the theme of the review?

- What are the popular decision approaches used by researchers to assess CESs rationally?

- What fuzzy sets are prominently used by researchers for CES assessment?

- What are commonly adopted metrics to evaluate the superiority of the proposed decision framework in the current field of study?

- What are the prevalent application areas addressed by researchers in the CES field and what are the future challenges, and how does the future research intuitively look for the current field of study?

The paper is further organized in the following way. Basic concepts related to decision approaches and different fuzzy sets are detailed in Section 2. The review model adopted in the current study and answers to the RQs are given in Section 3. The research challenges encountered for future research in CES, along with the discussion from the review, are given in Section 4. Finally, concluding remarks are provided in Section 5.

\section{Decision Approaches and Fuzzy Sets for CES}

This section outlines the different decision approaches that are used in the process of CES evaluation and assessment. Additionally, the problem is viewed from the context of uncertainty. Hence, the various fuzzy variants adopted are also outlined to give a preliminary insight into the frameworks that promote the evaluation of CESs.

\subsection{Decision-Making Methods}

Based on the previous review articles [8-11] in the field of CES evaluation, it is clear that the model frequently adopts integrated approaches, which involve weight estimation 
and a ranking method. Researchers often develop frameworks with these two critical ideas in the CES context. Weight is determined either with/without partial knowledge [12,13] on the criteria considered for rating CESs. The ranking is performed with the help of pairwise comparison methods, utility functions, or outranking relation-based methods [4,12-18].

Let us briefly discuss some weighting methods and ranking techniques (the list of the abbreviation and expansion of the main methods and approaches is contained in the Appendix A).

Analytical hierarchy process (AHP)

AHP $[19,20]$ is a popular ranking method that follows pairwise comparisons to determine the rank value of an alternative. The works provided in [21,22] describe the importance of AHP and its usefulness in various decision problems. From the review articles, it may be noted that AHP has been widely used by several fuzzy sets, and prominently for weight calculation and ranking. The works from [8-11] indicate that AHP is commonly used in the field of CESs.

Entropy

Entropy $[23,24]$ is another popular method used for weight calculation. The popular entropy measure is the Shannon version that is dominantly used for weight calculation. In the reviews [8-11], Shannon entropy is used by various fuzzy variants for weight calculation. The method is computationally viable, but does not capture interactions among criteria.

Criteria interaction through inter-correlation (CRITIC)

CRITIC [25,26] is an objective weight estimation approach, developed to properly understand the criteria interaction via correlation measures. Review articles [8-11] use this approach for criteria weight calculation, to enhance rationality during CES selection.

Stepwise weight assessment ratio analysis (SWARA)

SWARA [22] is also a popular approach for weight calculation, and determines weights objectively to aid in rational decision making. From [8-11], it is clear that SWARA is widely used for CES selection, and the sustainable criteria are better weighed using this approach. The work provided in [23] shows the variants of SWARA used in different decision applications under different fuzzy contexts.

Utility functions

Once the weights of the criteria are determined, CESs are ranked based on the problem being considered. As discussed earlier, utility function-based ranking is one type of ranking that is commonly used in CES evaluation under different fuzzy sets. The popular methods are complex proportional assessment (COPRAS) [24] and weight arithmetic sum product assessment (WASPAS) [25]. The main theme behind these two methods is that each vector is aggregated in a certain fashion, option-wise, and, finally, the options are arranged based on these values in decreasing order. A detailed review of COPRAS [26] and WASPAS [23] reveals that these two methods are popular and widely used in decision problems under diverse fuzzy contexts.

Compromise solution

The base idea for this ranking theme is adapted from the $L_{p}$ metric, with $p$ in the range of zero to infinity. A distance norm is used in the formulation to identify suitable options for the problem at hand. Frequently used methods under this category include TOPSIS and VIKOR [27], which follow the interesting comparative investigation and attempt to rank options differently. A review on TOPSIS [28-30] indicates that the method is quite often used in decision-making applications in diverse fields. Nevertheless, a review of the VIKOR method [31,32] also shows that the approach is used dominantly for decision making in several applications.

Outranking methods

Another interesting class of ranking is the outranking category, in which the ranking is performed based on outranking relations. Unlike the earlier categories, the values of each option are not directly aggregated, but are based on the conditions, and acceptance and conflict matrices are formulated that eventually form the ranking of diverse options. 
Popular methods include PROMETHEE [33] and ELECTRE [34], along with their variants. Reviews on PROMETHEE [35] and ELECTRE [36] clearly show their usefulness in decisionmaking applications.

It may be noted that, from the works presented in [8-11], it is clear that the utility and compromise approaches are commonly used for CES evaluation compared to outranking methods.

\subsection{Fuzzy Sets}

During the CESs evaluation process and its associated entities, uncertainty is an integral part of the process and cannot be simply ignored. To model the uncertainty better, researchers have adopted fuzzy sets and their variants. The typical strategy used by the researchers in this study involves the Likert-scale rating being transformed to respective fuzzy variants, and CESs being evaluated based on decision approaches. The works in [8-11] clearly show that classical fuzzy sets and their variants [37], intuitionistic fuzzy sets (IFS) [38], Pythagorean fuzzy sets (PFS) [39], and hesitant fuzzy sets (HFS) [40] are widely used in CES evaluation and support rational modelling of uncertainty. Reviews on IFS [41,42], PFS [43], and HFS [44] reveal their dominant usage in the decisionmaking process.

\section{Review Model}

This section describes the review model developed in this study for carrying out a bibliometric review of CES selection. Based on the past review articles presented above, the window for the current study is set to 2018 to 2021. Also, the authors identified that the bibliometric study was not conducted earlier, so some research questions on the theme are set. All the authors shared their views, and, finally, the questions were framed for the analysis. The keywords used in the study include "clean energy selection", "renewable energy selection using decision-making techniques", "clean energy selection in a fuzzy environment", and "clean energy selection using MCDM". The authors fed the keywords into the Web of Science ISI repository by setting the year bounds from 2018 to 2021, and obtained 542 articles. Later, the authors filtered the articles to obtain 133, by adopting manual reading and reviewing based on the relevance to the theme of the review process.

The authors read all these papers carefully and manually discarded some papers that did not cover the study's core theme. Based on the filtering process, 134 articles are most suitable for the review process during the 2018 to 2021 window. All these articles are from peer-reviewed journals.

A review model developed for properly reviewing the literature studies from 2018 to 2021 is shown in Figure 1. The model initially collects raw data from the Web of Science ISI repository by feeding the desired keywords. Later, the authors read the articles carefully and manually performed filtering of articles based on the core theme of the study. The bibliometric context is adopted to analyze the filtered articles. The authors framed the RQs carefully to obtain interesting information related to the CES field. Tabulations are presented to address the raised RQs, along with an informative description of the tabulated content. Readers are requested to refer to the next section for clarity. 


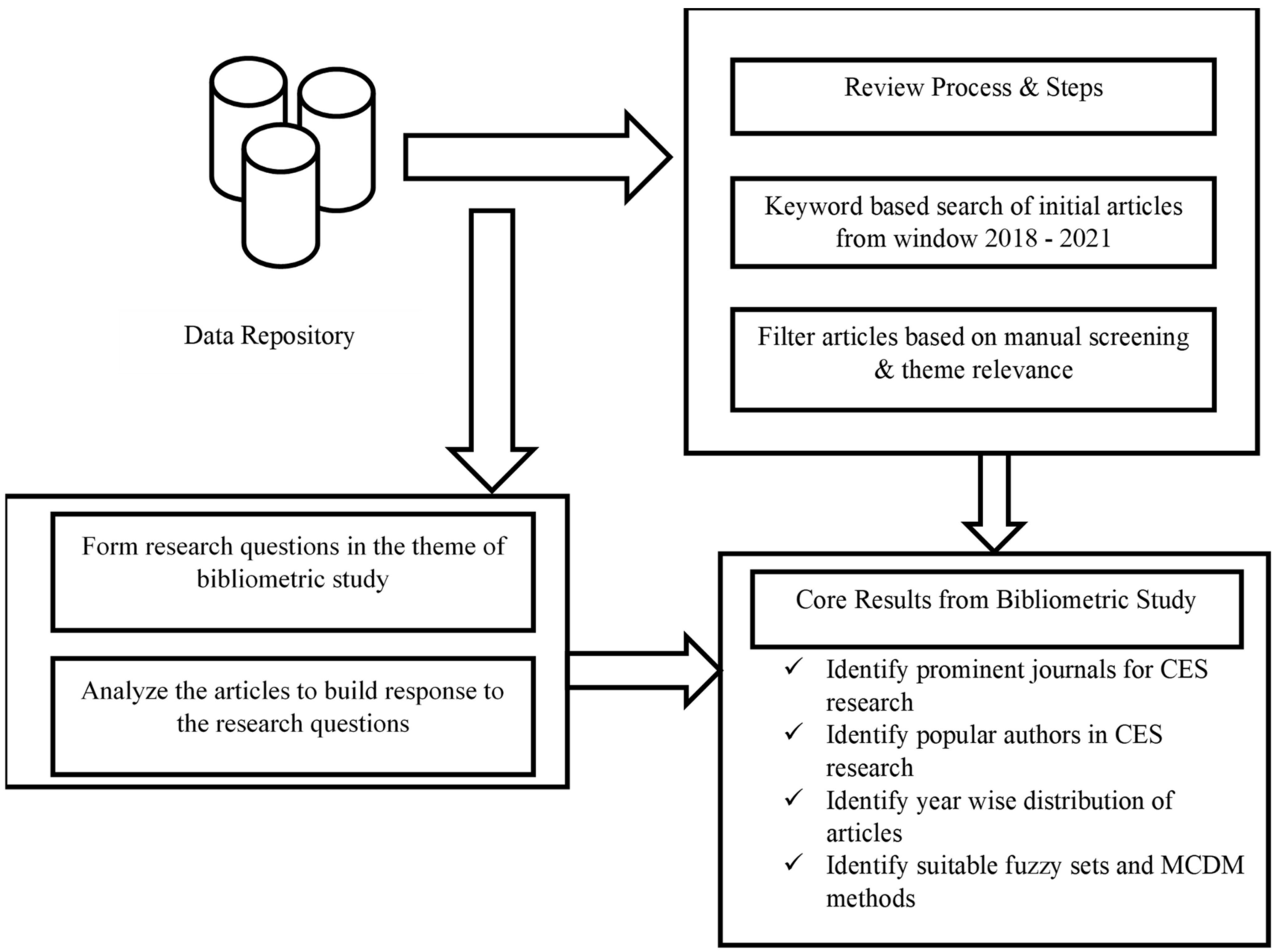

Figure 1. Overview of the review model.

\section{Results and Discussion}

\subsection{Response to RQs}

(RQ 1)-What are the popular decision approaches used by researchers to assess CESs rationally?

In this review paper, 76 decision-making approaches have been identified. Some of them have been modified in their respective study to improve the output and obtain better solutions. Table 1 shows the distribution of all the decision approaches used in all the papers studied here. In this distribution, one may use the numerical indexing of each method at the bottom of the table and observe the trend of each method used in the sample of journals included in this study. Each entry from the columns numbered 1 to 8 represents the methods 1 to 8; for instance, if, for any given author, there is a mark in column 1, it should be concluded that the author has made use of the analytical hierarchal process (AHP).

Table 1. Distribution of decision approaches in CES study (2018-2021).

\begin{tabular}{|c|c|c|c|c|c|c|c|c|c|c|}
\hline Author & Year & 1 & 2 & 3 & 4 & 5 & 6 & 7 & 8 & Others \\
\hline Wu et al. [45] & 2018 & $\checkmark$ & & & & & & & & \\
\hline Wang et al. [46] & 2018 & $\checkmark$ & & & & & & $\checkmark$ & & \\
\hline Büyüközkan et al. [47] & 2018 & $\checkmark$ & & & & & & & & 65 \\
\hline Promentilla et al. [48] & 2018 & $\checkmark$ & & & & & & & & 66 \\
\hline Lee et al. [49] & 2018 & & & & & $\checkmark$ & $\checkmark$ & $\checkmark$ & & 54 \\
\hline Ghimire \& Kim [50] & 2018 & $\checkmark$ & & & & & & & & \\
\hline
\end{tabular}


Table 1. Cont

\begin{tabular}{|c|c|c|c|c|c|c|c|c|c|c|}
\hline Author & Year & 1 & 2 & 3 & 4 & 5 & 6 & 7 & 8 & Others \\
\hline Chatterjee \& Kar [51] & 2018 & & $\checkmark$ & & & & & & & \\
\hline Chen \& Ren [52] & 2018 & & $\checkmark$ & & & & & $\checkmark$ & & \\
\hline Boran [53] & 2018 & & & & & $\checkmark$ & & & & \\
\hline Simsek et al. [54] & 2018 & & & & & & & & & 10 \\
\hline Sehatpour et al. [55] & 2018 & & & & & & & & & 17 \\
\hline Li et al. [56] & 2018 & & & & & & & & & 30 \\
\hline Alizadeh et al. [57] & 2018 & & $\checkmark$ & & & & & & & \\
\hline Liu et al. [58] & 2019 & & & & & & & $\checkmark$ & & 9 \\
\hline Cerón et al. [59] & 2019 & & & & & & & & & 20 \\
\hline Tarybakhsh et al. [60] & 2019 & & & & & & & & & $11,53,67$ \\
\hline Mostafaeipour \& Sadeghi-Sedeh [61] & 2019 & $\checkmark$ & & & & $\checkmark$ & & $\checkmark$ & & 48,55 \\
\hline Deo et al. [62] & 2019 & & & & & & & & & $12,1417,18$ \\
\hline Kumar et al. [63] & 2019 & & & & & & & & & \\
\hline Essien et al. [64] & 2019 & & & & & & & & & \\
\hline Rani et al. [65] & 2019 & & & & & $\checkmark$ & & $\checkmark$ & & 45 \\
\hline Karunathilake et al. [66] & 2019 & $\checkmark$ & & & & & & $\checkmark$ & & \\
\hline Krishankumar et al. [67] & 2019 & & & & & & & & & 65 \\
\hline Krishankumar et al. [68] & 2020 & & & & & & & $\checkmark$ & & \\
\hline Rani et al. [69] & 2020 & & & & & $\checkmark$ & & & & \\
\hline Yousef et al. [70] & 2020 & & & $\checkmark$ & & & & & & 56 \\
\hline Asif et al. [71] & 2020 & & & & & & & & & 57 \\
\hline Muneeza et al. [72] & 2020 & & $\checkmark$ & & & $\checkmark$ & & $\checkmark$ & & 22 \\
\hline Wu et al. [73] & 2020 & & & & & & & & & 23 \\
\hline Okokpujie et al. [74] & 2020 & $\checkmark$ & & & & & & $\checkmark$ & & \\
\hline Guðlaugsson et al. [75] & 2020 & & & & & & & & & \\
\hline Luo et al. [76] & 2020 & & $\checkmark$ & & & & & $\checkmark$ & & 61 \\
\hline Papanikolaou et al. [77] & 2020 & & & & & & & $\checkmark$ & & \\
\hline Wang et al. [78] & 2020 & $\checkmark$ & & & & & & & & \\
\hline Kamari et al. [79] & 2020 & $\checkmark$ & & & & & & & & 40,65 \\
\hline Alkan \& Albayrak [80] & 2020 & & & & & & & & & \\
\hline Song et al. [81] & 2020 & & & & & & & & & \\
\hline Hu et al. [82] & 2020 & & & & & & & $\checkmark$ & & \\
\hline Karaşan et al. [83] & 2020 & $\checkmark$ & & & & & & & & \\
\hline Ikram et al. [84] & 2020 & $\checkmark$ & & & & $\checkmark$ & & & $\checkmark$ & \\
\hline Guleria \& Bajaj [85] & 2020 & & & & & $\checkmark$ & & $\checkmark$ & $\checkmark$ & \\
\hline Ahmadi et al. [86] & 2020 & & $\checkmark$ & & & $\checkmark$ & & & & 25 \\
\hline Li et al. [87] & 2020 & & & & & & & & & 26 \\
\hline Arriola et al. [88] & 2020 & & & $\checkmark$ & & & & $\checkmark$ & & $13,17,40,59$ \\
\hline Albawab et al. [89] & 2020 & & & & & & & & & 27,28 \\
\hline Wang et al. [90] & 2020 & $\checkmark$ & & & & & & $\checkmark$ & & 29 \\
\hline Deveci et al. [91] & 2020 & $\checkmark$ & & & & & & & & $19,31,61$ \\
\hline Aryanfar et al. [92] & 2020 & $\checkmark$ & & & & & & & & 41 \\
\hline Rivera-Niquepa et al. [93] & 2020 & & & & & & & & & 32 \\
\hline Ali et al. [94] & 2020 & & & & & & & & & $16,33,34,35,36$ \\
\hline Afzal \& Ramis [95] & 2020 & & & $\checkmark$ & $\checkmark$ & & & & & $13,37,38,39$ \\
\hline Xu et al. [96] & 2020 & & $\checkmark$ & & & & & $\checkmark$ & & 41 \\
\hline Wu et al. [97] & 2020 & & & & & & & & & 41,55 \\
\hline Mangla et al. [98] & 2020 & $\checkmark$ & $\checkmark$ & & & & & & & 41 \\
\hline Mokarram et al. [99] & 2020 & $\checkmark$ & $\checkmark$ & & & & & & & \\
\hline Moradi et al. [100] & 2020 & $\checkmark$ & $\checkmark$ & & & & & & & \\
\hline Çolak \& Kaya [101] & 2020 & $\checkmark$ & $\checkmark$ & & & $\checkmark$ & & $\checkmark$ & & \\
\hline Adedeji et al. [102] & 2020 & & & & & & & & & \\
\hline Geng et al. [103] & 2020 & & & & & & & & & \\
\hline Alao et al. [104] & 2020 & & & & & & & $\checkmark$ & & \\
\hline Pamucar et al. [105] & 2020 & & & & & & & & & 43,61 \\
\hline Wu et al. [106] & 2020 & & & & & & & & & 23 \\
\hline Wu et al. [107] & 2020 & & $\checkmark$ & & & & & & & 42 \\
\hline Cheng et al. [108] & 2020 & & & & & & & $\checkmark$ & & 41 \\
\hline Tarife et al. [109] & 2020 & & & & & & & & & \\
\hline Feng [110] & 2021 & $\checkmark$ & & & & & & & & \\
\hline Mrówczyńska et al. [111] & 2021 & $\checkmark$ & & & & & & & & \\
\hline Kumar et al. [112] & 2021 & $\checkmark$ & & & & & & $\checkmark$ & & \\
\hline Krishankumar et al. [113] & 2021 & & & & & & & & & $21,55,62$ \\
\hline Liu et al. [114] & 2021 & $\checkmark$ & & & & $\checkmark$ & & & & 46 \\
\hline Ahmad et al. [115] & 2021 & & & & & $\checkmark$ & & $\checkmark$ & & 23 \\
\hline Hashmi et al. [116] & 2021 & & & & $\checkmark$ & & & & & 17,47 \\
\hline
\end{tabular}


Table 1. Cont.

\begin{tabular}{|c|c|c|c|c|c|c|c|c|c|c|}
\hline Author & Year & 1 & 2 & 3 & 4 & 5 & 6 & 7 & 8 & Others \\
\hline Fetanat et al. [117] & 2021 & & & & & & & & $\checkmark$ & 60 \\
\hline Wu et al. [118] & 2021 & $\checkmark$ & & & & & & & & 41 \\
\hline Adedeji et al. [119] & 2021 & & & $\checkmark$ & & & & & & 13 \\
\hline Malik \& Yadav [120] & 2021 & & & & & & & & & 63 \\
\hline Gulzar et al. [121] & 2021 & & & & & & & & & 13,49 \\
\hline Kotb et al. [122] & 2021 & $\checkmark$ & & & & $\checkmark$ & & & & \\
\hline Lin et al. [123] & 2021 & & & & & & & & & \\
\hline Wang et al. [124] & 2021 & & & & & & & & & 50 \\
\hline Wang et al. [125] & 2021 & & & & & & & & $\checkmark$ & 40 \\
\hline Mei \& Chen [126] & 2021 & & & & & & & & & 41 \\
\hline Yang \& Chang [127] & 2021 & & & & & & & & & 51 \\
\hline Clauberg et al. [128] & 2021 & & & & & & & & & \\
\hline Yazır et al. [129] & 2021 & & & & & & & & & \\
\hline Sun \& Yu [130] & 2021 & & & & & & & $\checkmark$ & $\checkmark$ & 15,52 \\
\hline Huai et al. [131] & 2021 & & & & & & & & & 64 \\
\hline Mostafaeipour et al. [132] & 2021 & & & & & & & & & 35,61 \\
\hline Balezentis et al. [133] & 2021 & & & & & & & & & 16,61 \\
\hline Ghouchani et al. [134] & 2021 & & & & & & & & & 19 \\
\hline Ullah et al. [135] & 2021 & & $\checkmark$ & & & & & $\checkmark$ & & 35,40 \\
\hline Cayir Ervural et al. [136] & 2021 & & & $\checkmark$ & & & & $\checkmark$ & & \\
\hline Wang et al. [137] & 2021 & & & & & & & $\checkmark$ & & 68 \\
\hline Liu et al. [138] & 2021 & & & $\checkmark$ & & & & & & 41 \\
\hline Gökgöz \& Yalçın [139] & 2021 & & & & & & & & & $10,29,64$ \\
\hline Ulutaş \& Karaca. [140] & 2021 & & & & & & & & & 29,65 \\
\hline Malemnganbi \& Shimray [141] & 2021 & $\checkmark$ & & & & & & & & \\
\hline Ecer [142] & 2021 & & & & & & & & & $27,43,65$ \\
\hline Ramos-Escudero [143] & 2021 & & & & & $\checkmark$ & & & & \\
\hline Gkeka-Serpetsidaki \& Tsoutsos [144] & 2021 & $\checkmark$ & & & & & & & & \\
\hline Kannan et al. [145] & 2021 & & & & & $\checkmark$ & & & & $61,64,69$ \\
\hline Abdul-Basset et al. [146] & 2021 & $\checkmark$ & & & & & & & & 35 \\
\hline Xie et al. [147] & 2021 & & & & & & & & & 41 \\
\hline Saraswat \& Digalwar [148] & 2021 & $\checkmark$ & & & & & & & $\checkmark$ & \\
\hline Pan \& Wang [149] & 2021 & & & & & & & & & 58 \\
\hline Karaaslan et al. [150] & 2021 & $\checkmark$ & & & & & & & & 43 \\
\hline Dang et al. [151] & 2021 & & & & & $\checkmark$ & & & & \\
\hline Qazi et al. [152] & 2021 & & & & & & & $\checkmark$ & & \\
\hline Karatop et al. [153] & 2021 & $\checkmark$ & & & & & & & & 35 \\
\hline Günen [154] & 2021 & $\checkmark$ & & & & & & & & \\
\hline Akçay \& Atak [155] & 2018 & $\checkmark$ & & & & & & $\checkmark$ & & \\
\hline Dominguez et al. [156] & 2021 & & & & & & & & & 77 \\
\hline Lin \& Ren [157] & 2021 & & & & & & & & & \\
\hline Shorabeh et al. [158] & 2021 & & $\checkmark$ & & & & & $\checkmark$ & & \\
\hline Lopes et al. [159] & 2021 & & & & & & & $\checkmark$ & & \\
\hline Rahoma \& Obeidat [160] & 2021 & & & & & & & & & \\
\hline Ajanaku et al. [161] & 2021 & $\checkmark$ & & & & & & & & \\
\hline Asanza et al. [162] & 2021 & $\checkmark$ & & & & & & & & \\
\hline Ulewicz et al. [163] & 2021 & $\checkmark$ & & & & & & $\checkmark$ & & \\
\hline Crivellari et al. [164] & 2021 & & & & & & & & & 69 \\
\hline Babatunde et al. [165] & 2021 & & & & & & & & & 35 \\
\hline Prieto-Amparán et al. [166] & 2021 & $\checkmark$ & & & & & & & & \\
\hline Tercan et al. [167] & 2021 & $\checkmark$ & & & & & & & & \\
\hline Hwang et al. [168] & 2021 & & & & & & & & & \\
\hline Naegler et al. [169] & 2021 & & & & & & $\checkmark$ & & & \\
\hline Sipa [170] & 2021 & & & & & & & & & 40 \\
\hline Lucheroni et al. [171] & 2021 & & & & & & & & & 71 \\
\hline Castangia et al. [172] & 2021 & & & & & & & & & 26 \\
\hline Bertolino et al. [173] & 2021 & & & & & & & & & 72 \\
\hline Derbeli et al. [174] & 2021 & & & & & & & & & 56 \\
\hline Mohd et al. [175] & 2021 & & & & & & & & & 73 \\
\hline Alam et al. [176] & 2021 & & & & & & & & & 74 \\
\hline Alberizzi et al. [177] & 2021 & & & & & & & & & 20 \\
\hline Martin-Hernandez et al. [178] & 2021 & & & & & & & & & 75 \\
\hline Oregi et al. [179] & 2021 & & & & & & & & & 76 \\
\hline
\end{tabular}


Table 1. Cont

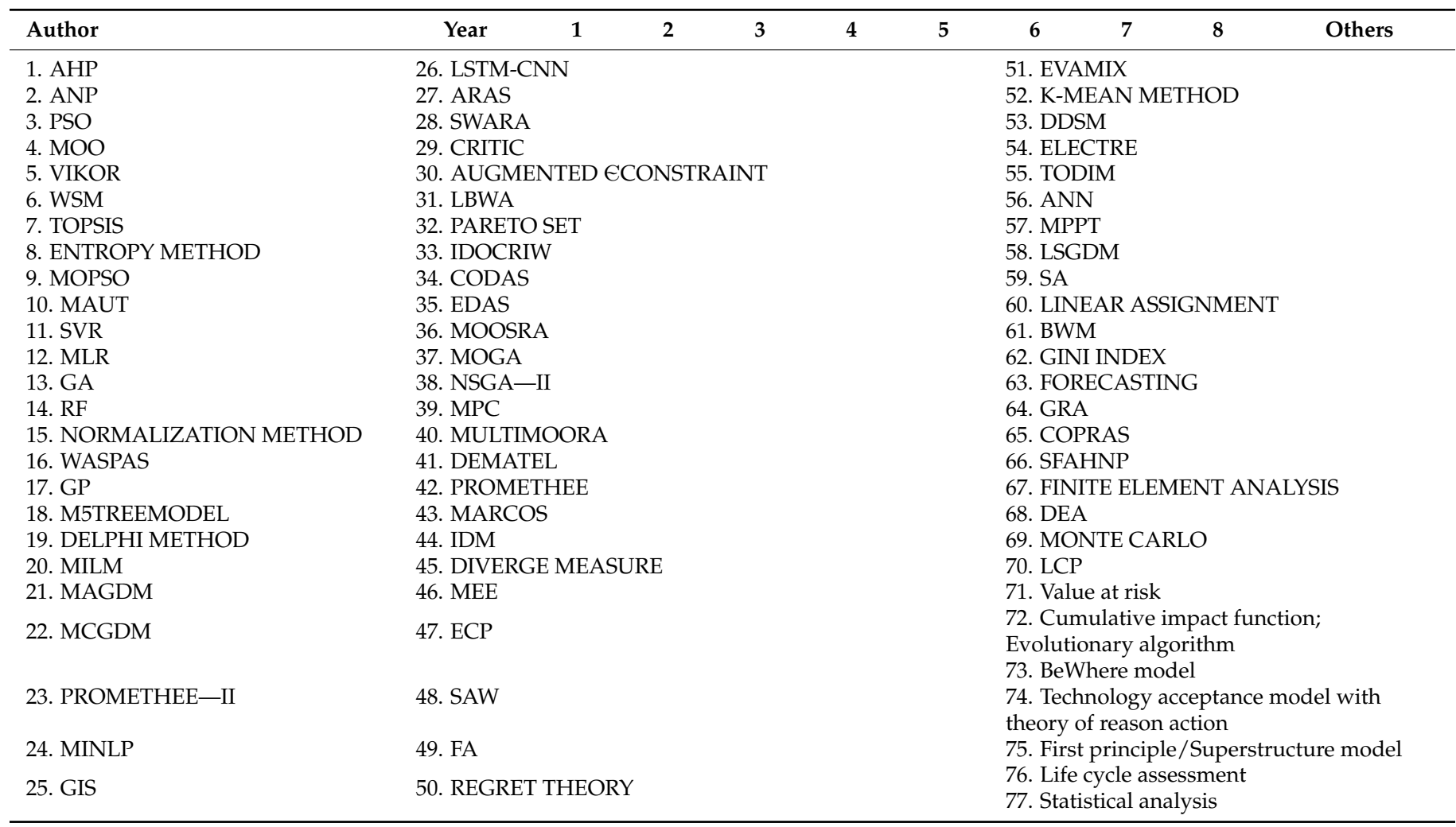

Similarly, a mark in column 8 represents that the author has used the entropy method for their study. The column "others" includes the numerical index of the methods themselves. If a particular author has multiple marks in their corresponding row, it is implied that multiple methods have been used together. A similar study approach has been used in other tables as well. It is to be noted that Table 1 considers the decision methods used in the existing works and not the environment.

Moreover, this study considers their principal method as the method classifier; for instance, vector-aided technique for order of preference by similarity to ideal solution (TOPSIS) and entropy-based TOPSIS will be classified in the same name class (TOPSIS). However, discretion is required for generalization. In addition, the reader will come across numerous cases where the author has used various methods, such as data envelopment analysis (DEA), additive ratio assessment (ARAS), and analytical hierarchal process (AHP), for the study. For such cases, the authors consider the method that the works used for ranking/selecting CES.

The distribution of the most frequently used decision approaches that are in trend in CES is shown in Table 2. The AHP (analytical hierarchy process) has been used in 38 studies. It covers approximately 31 percent of the content in this review. Bing et al., (2018) used an approach to establish a three-layer decision-making framework, after identifying the influencing factors from previous works, derive the decision matrix by integrating the influencing factor, and obtain the attributes' weights by using the AHP [45]. Wang et al., (2018) conducted research in multiple stages. The first stage includes a fuzzy-AHP model for determining the weight of each potential location for building a wind power plant based on qualitative and quantitative factors.

Furthermore, a TOPSIS approach ranks all the potential alternatives in the final stage [46]. Promentilla et al., (2018) proposes an SFAHNP decision model to address the complexity and uncertainty involved in the clean technology selection process. This method first decomposes the problem into a hierarchical network structure, and then derives the probability distribution of the priority weights needed for ranking [48]. In 
2020, Kamari et al., published their research work using fuzzy sets and AHP to extract the necessary criteria for decision making for renewable energy systems [79].

Table 2. The four most prominent decision approaches used in the CES study (window 2018 to 2021).

\begin{tabular}{cccc}
\hline Method & Studies & Total & Percentage (\%) \\
\hline AHP & {$[45-48,50,61,66,74-76,80,81,87-89,95,98,107-111,118,121,141,144,147,148,150,153-$} & 38 & $30.4 \%$ \\
& $155,161-163,166,167]$ & 31 & $24.8 \%$ \\
TOPSIS & {$[46,49,52,58,61,68,69,72,74,76,77,82,85,88,90,96,104,108,112,115,130,135-$} & 16 & $12.8 \%$ \\
VIKOR & $137,152,155,158,159,163]$ & 14 & $11.2 \%$ \\
ANP & {$[49,53,61,66,68,69,73,83,98,111,112,119,140,142,148]$} & $151,52,57,72,76,86,95-98,107,132,155]$ & \\
\hline
\end{tabular}

Note: These four methods cover almost $79 \%$ of the total articles considered for the review process. Other ranking methods cover the remaining $21 \%$.

TOPSIS (technique for order preference by similarity to ideal solution) has been used in over 31 studies. Lee et al., (2018) performed a comparative analysis of ranking renewable energy sources (RES) for electricity generation in Taiwan, using four MCDM methods-WSM, VIKOR, TOPSIS, and ELECTRE. This study aims to rank the priorities of various RES and propose recommendations for Taiwan's RES development [49]. Chen et al., (2018) developed a multi-attribute sustainability evaluation model for assessing various alternative aviation fuels [52]. Liu et al., (2019) performed an analysis using TOPSIS and VIKOR to study the level of sustainable development of the EU countries. Indicators from the main goals of the SDGs (Sustainable Development Goals) were used for this study [58].

The ANP (analytical network process) has been used 14 times, covering approximately 11 percent. Chen et al., (2018) provided a study to evaluate a multi-attribute sustainability evaluation model for assessing various alternative aviation fuels [52]. VIKOR (Visekriterijumska Optimizacija I Kompromisno Resenje) and PSO (particle swarm optimization) have been used 8 and 4 times, respectively, and equate to 8 and 4 percent of this study. The top five approaches, out of 64 approaches, cumulate about $66 \%$ of the total survey.

(RQ 2)-What fuzzy sets are prominently used by researchers for CES assessment?

Table 3 presents the distribution of 8 fuzzy set variants over 134 scholarly research papers, published in 38 journals. These articles presented the core fuzzy/linguistic variants of the ranking schemes for CES evaluation. A numbering system has been introduced to identify all the fuzzy and linguistic approaches and sets. Prominent fuzzy approaches and the most frequently used fuzzy sets have been identified from the study. It has been concluded, from the data, that the fuzzy concept is the most prominent type of method implemented in a range of papers. Research papers have used fuzzy concepts either in their traditional form or variants, and some works have also considered linguistic versions to handle uncertainty.

Table 3. Distribution of fuzzy sets and variants used in decision models for CES study (2018-2021).

\begin{tabular}{|c|c|c|c|c|c|c|c|c|c|}
\hline Author & Year & 1 & 2 & 3 & 4 & 5 & 6 & 7 & 8 \\
\hline Büyüközkan et al. [47] & 2018 & $\checkmark$ & & & & & & & \\
\hline Ghimire \& Kim [50] & 2018 & & $\checkmark$ & & & & & & \\
\hline Sehatpour et al. [55] & 2018 & & $\checkmark$ & & & & & & \\
\hline Tarybakhsh et al. [60] & 2019 & & & $\checkmark$ & & & & & \\
\hline Deo et al. [62] & 2019 & & $\checkmark$ & & & & & & \\
\hline Kumar et al. [63] & 2019 & $\checkmark$ & & & & & & & \\
\hline Essien et al. [64] & 2019 & & & $\checkmark$ & & & & & \\
\hline Rani et al. [65] & 2019 & & & $\checkmark$ & & & & & \\
\hline Karunathilake et al. [66] & 2019 & $\checkmark$ & & & & & & & \\
\hline Krishankumar et al. [67] & 2019 & & $\checkmark$ & & & $\checkmark$ & & & \\
\hline Krishankumar et al. [68] & 2020 & & & & & & & & $\checkmark$ \\
\hline Rani et al. [69] & 2020 & $\checkmark$ & & & & & & & \\
\hline Yousef et al. [70] & 2020 & $\checkmark$ & & & & & & & \\
\hline Asif et al. [71] & 2020 & $\checkmark$ & & & & & & & \\
\hline Wu et al. [73] & 2020 & & & $\checkmark$ & & & & & \\
\hline
\end{tabular}


Table 3. Cont.

\begin{tabular}{|c|c|c|c|c|c|c|c|c|c|}
\hline Author & Year & 1 & 2 & 3 & 4 & 5 & 6 & 7 & 8 \\
\hline Guðlaugsson et al. [75] & 2020 & $\checkmark$ & & & & & & & \\
\hline Luo et al. [76] & 2020 & $\checkmark$ & & & & & & & \\
\hline Kamari et al. [79] & 2020 & & & $\checkmark$ & & & & & \\
\hline Alkan et al. [80] & 2020 & & & $\checkmark$ & & & & & \\
\hline Hu et al. [82] & 2020 & & $\checkmark$ & & & & & & $\checkmark$ \\
\hline Karaşan et al. [83] & 2020 & $\checkmark$ & & & & & & $\checkmark$ & \\
\hline Guleria \& Bajaj [85] & 2020 & & & & & & & $\checkmark$ & \\
\hline Arriola et al. [88] & 2020 & $\checkmark$ & & & & & & & \\
\hline Deveci et al. [91] & 2020 & & $\checkmark$ & $\checkmark$ & & & & & \\
\hline Aryanfar et al. [92] & 2020 & $\checkmark$ & & & & & & & \\
\hline Xu et al. [96] & 2020 & & & $\checkmark$ & & & & & \\
\hline Wu et al. [97] & 2020 & & & $\checkmark$ & & & & & \\
\hline Çolak \& Kaya [101] & 2020 & $\checkmark$ & & $\checkmark$ & & & & & \\
\hline Adedeji et al. [102] & 2020 & & & $\checkmark$ & & & & & \\
\hline Geng et al. [103] & 2020 & & $\checkmark$ & $\checkmark$ & & & & & \\
\hline Pamucar et al. [105] & 2020 & & & $\checkmark$ & & & & & \\
\hline Wu et al. [106] & 2020 & & & $\checkmark$ & & & & & \\
\hline Cheng et al. [108] & 2020 & $\checkmark$ & $\checkmark$ & & & & & & \\
\hline Feng [110] & 2021 & & & $\checkmark$ & & & & & \\
\hline Mrówczyńska et al. [111] & 2021 & $\checkmark$ & & & & & & & \\
\hline Krishankumar et al. [113] & 2021 & & & & & $\checkmark$ & & & \\
\hline Wu et al. [118] & 2021 & & & $\checkmark$ & & & & & \\
\hline Adedeji et al. [119] & 2021 & & & & & $\checkmark$ & & & \\
\hline Wang et al. [124] & 2021 & & & & $\checkmark$ & & & & \\
\hline Wang et al. [125] & 2021 & & & $\checkmark$ & & & & & \\
\hline Yang \& Chang [127] & 2021 & & & & & $\checkmark$ & & & \\
\hline Clauberg et al. [128] & 2021 & & & $\checkmark$ & & & & & \\
\hline Yazır \& Şahin [129] & 2021 & & & $\checkmark$ & & & & & \\
\hline Sun \& Yu [130] & 2021 & & & $\checkmark$ & & & & & \\
\hline Mostafaeipour et al. [132] & 2021 & & & $\checkmark$ & & & & & \\
\hline Wang et al. [137] & 2021 & & & $\checkmark$ & & & & & \\
\hline Liu et al. [138] & 2021 & & & & & & & & $\checkmark$ \\
\hline Abdul-Basset et al. [146] & 2021 & & & & & & $\checkmark$ & & \\
\hline Xie et al. [147] & 2021 & & & $\checkmark$ & & & & & \\
\hline Pan \& Wang [149] & 2021 & & & & $\checkmark$ & & & & \\
\hline Dang et al. [151] & 2021 & & & $\checkmark$ & & & & & \\
\hline Karatop et al. [153] & 2021 & & & $\checkmark$ & & & & & \\
\hline \multicolumn{10}{|c|}{ 1. hesitant fuzzy set variants } \\
\hline \multicolumn{10}{|c|}{ 2. intuitionistic fuzzy set variants } \\
\hline \multicolumn{10}{|c|}{ 3. classical fuzzy set variants } \\
\hline \multicolumn{10}{|c|}{ 4. linguistic term set variants } \\
\hline \multicolumn{10}{|c|}{ 5. q-rung orthopair fuzzy set } \\
\hline \multicolumn{10}{|c|}{ 6. neutrosophic fuzzy set variants } \\
\hline \multicolumn{10}{|c|}{ 7. Pythagorean fuzzy set variants } \\
\hline 8. interval fuzzy set vari & & & & & & & & & \\
\hline
\end{tabular}

The data show that orthopair versions of fuzzy sets have been widely used to study CES under uncertainty. However, recent studies have also started considering linguistic information directly for CES assessment. Hesitant fuzzy set variants have been observed in 14 studies. Classical fuzzy set variants have been employed in 24 studies, in over 134 papers that have been included in this review.

In 2019, Tarybakhsh et al., conducted a study using an integrated data-driven screening model (DDSM) to improve EOR screening, using the combined capabilities of the fuzzy expert approach (FEA) and support vector regression (SVR) techniques. EOR field data from the past 40 years were reviewed to generate an updated and reliable EOR criteria table as a basis to construct a fuzzy screening model [60]. In the same year, Karunathilake et al., conducted a study using fuzzy logic, fuzzy TOPSIS, trapezoidal fuzzy number, and triangular fuzzy number. However, such decision-making methods are affected by problems such as rank reversal when alternatives are added or removed. The focus of this study was to demonstrate a decision-making process for a community-level energy system; however, further exploring this aspect was considered to be out of its scope [66]. Even though approaches have been identified, a clear distinction cannot be made, since 
they have been used simultaneously with several other approaches. It is shown that the type of fuzzy sets most used among the 126 studies are triangular fuzzy number and fuzzy sets. They have been used with other different sets, such as hesitant and interval group sets. In 2018, Büyüközkan et al., published research work in the Energy Journal, using the HFL term set, HFL-AHP, and HFL-COPRAS to addresses this research gap, and introduced a numerical decision support method for identifying the most suitable renewable energy sources [47]. The same year, Lixia et al., published their study in the Journal of Hydrology, developing an inexact interval-valued triangular fuzzy-based multiattribute preference model (IVTF-MAPM) method to support the selection of remediation strategies of groundwater remediation. Yousef et al., (2020) used experimental data and fuzzy logic to build a robust model that describes the yield of bio-methanol production. Then, the particle swarm optimization (PSO) algorithm was utilized to estimate the optimal values of the operating parameters that maximize the bio-methanol yield [70].

(RQ 3)_Which countries prominently contributed to CES-related research?

A study of the countries where CES research prominently occurs, based on the collected data in the window from 2018 to 2021, has been performed, and is shown in Table 4 . It can be observed that some countries are more inclined to a site selection type of decision making, while others are focused towards the source of clean energy. It can be observed that countries such as China, Turkey, and India perform decision making on CES-related fields prominently, compared to Malaysia, Mexico, Serbia, and so on. Readers need to note that these claims are based on the 134 articles collected by the authors in the window from 2018 to 2021. Also, the country with which the first author is affiliated in the research article is taken and depicted in Table 4.

Table 4. Country-wise distribution articles pertaining to CES research.

\begin{tabular}{|c|c|c|}
\hline Country & Papers & Percentage \\
\hline China & 30 & $22.4 \%$ \\
\hline Turkey & 15 & $11.2 \%$ \\
\hline India & 14 & $10.5 \%$ \\
\hline Iran & 10 & $7.5 \%$ \\
\hline Pakistan & 4 & $3 \%$ \\
\hline Taiwan & 4 & $3 \%$ \\
\hline Brazil & 3 & $2.2 \%$ \\
\hline Nigeria & 3 & $2.2 \%$ \\
\hline Poland & 3 & $2.2 \%$ \\
\hline Australia & 2 & $1.5 \%$ \\
\hline Canada & 2 & $1.5 \%$ \\
\hline Colombia & 2 & $1.5 \%$ \\
\hline Egypt & 1 & $0.7 \%$ \\
\hline Germany & 1 & $0.7 \%$ \\
\hline Singapore & 2 & $1.5 \%$ \\
\hline South Africa & 2 & $1.5 \%$ \\
\hline United Arab Emirates & 2 & $1.5 \%$ \\
\hline United Kingdom & 2 & $1.5 \%$ \\
\hline USA & 3 & $2.2 \%$ \\
\hline Vietnam & 2 & $1.5 \%$ \\
\hline Japan & 2 & $1.5 \%$ \\
\hline Chile & 1 & \\
\hline Denmark & 1 & \\
\hline France & 1 & \\
\hline Greece & 1 & \\
\hline Hungary & 1 & \\
\hline Iceland & 1 & $14 \times 0.7=10.5 \% ; 3.7 \% ; 3 \% ; 2.2 \%$ \\
\hline Italy & 5 & \\
\hline Jordan & 1 & \\
\hline Lithuanian & 1 & \\
\hline Malaysia & 3 & \\
\hline
\end{tabular}


Table 4. Cont.

\begin{tabular}{ccc}
\hline Country & Papers & Percentage \\
\hline Mexico & 1 & \\
Philippines & 1 & \\
Serbia & 1 & \\
Spain & 4 & \\
Sri Lanka & 1 & \\
Uzbekistan & 1 & $100 \%$ \\
South Korea & 1 & \\
\hline Total & 134 & \\
\hline
\end{tabular}

The first column represents the source/reference number. The next column includes the country with which the first author is affiliated. This is followed by a column consisting of the counts of research papers. A frequency distribution based on the first author's affiliated country has been calculated in Table 4. China leads the "clean energy selection" research by a huge margin for the sample data of 134 research papers. The research area is in site selection, energy selection, energy system selection, and so on. China contributes to 30 research papers between 2018 and 2021, contributing to around 23\% of the total research in the field. Extensive research into both offshore and onshore site selection for wind farms has been a trend in the considered papers. A major section of studies also conducted works in areas related to solar energy, including photovoltaic cells, solar ponds for desalination, site selection for better power output, and affordability. Hydrogen energy also received much attention in the selected sample. Much of the research has been performed on desalination, solar and wind energy, and waste management.

In 2020, Xu et al., developed a novel mathematical framework that assesses the sustainability of different renewable energy-powered desalination systems, which is essential for their portfolio selection, by resorting to the fuzzy multi-attribute decision-making (MAMD) methods. In the framework, an evaluation system including ten attributes from four dimensions is introduced. At the same time, fuzzy triangular numbers and interval values are employed to capture the epistemic and aleatory uncertainties of decision information, respectively [96]. Similarly, another study was conducted to analyze strengths, weaknesses, opportunities, and threats (SWOT), to evaluate the external and internal factors that affect the RET (renewable energy technologies) in Sindh and Baluchistan province. This study uses the fuzzy analytical hierarchy process method, with a multi-perspective approach, including economic, environmental, technical, and socio-political criteria. The study considers four criteria, seventeen sub-criteria, and three RETs - solar, wind, and biomass. Each has been assessed as an alternative in the decision model, to conclude that economic and socio-political criteria are the two most essential criteria in the region, and will be the deciding factor. Moreover, the study also reveals that wind can generate electricity in Sindh and Baluchistan provinces.

(RQ 4)-Who are the prominent first authors in the CES assessment field based on the collected articles from the window 2018 to 2021?

We have identified prominent first authors in the CES field, based on the collected data for the past four years. Wu has published four research papers using AHP, ANP, and PROMETHEE. Krishankumar has authored three papers in the time frame of 2018 to 2021. Rani et al., has contributed to two research studies on clean energy selection (see the Table 5). Approaches such as VIKOR and divergence measures are used in the study with fuzzy/variants information.

(RQ 5)-Which are the popular journals covering research in the CES field?

Table 6 shows the distribution of 12 publishers and 64 internationally accepted journals. The first column represents the journals included in this study. The following column entails the indices on the research paper published in that journal. An analysis shows that Elsevier has a total of 57 research papers from 24 journals. The highest number of research work has been identified from the "Journal of Cleaner Production". Twelve research 
papers have been published in this journal. Elsevier further contributes to seven research works from the "Journal of Energy Storage". John Wiley and Son's publishers contribute to 9 journals that provide 18 studies. The International Journal of Energy Research contributes to six research works in this study. Five more journals, from three publishers, are responsible for the rest of the research work considered.

Table 5. List of first authors in the CES field who published two or more works (based on the articles collected from 2018 to 2021).

\begin{tabular}{ccc}
\hline Author Names & Country (Affiliation) & Research Papers \\
\hline Yunna Wu. & China & 4 \\
Raghunathan Krishankumar & India & 3 \\
Pratibha Rani & India & 2 \\
Mahya Ghouchani & Iran & 2 \\
Paul A. Adedeji & South Africa & 2 \\
\hline
\end{tabular}

Table 6. Distribution of papers based on journals and publishers.

\begin{tabular}{|c|c|c|c|}
\hline Publisher & Journal Name & Count of Paper & Percentage \\
\hline \multirow{2}{*}{ Academic Press Inc. } & Environmental Research & 1 & \multirow{7}{*}{$7 \times 0.75=5.25 \%$} \\
\hline & Journal of Environmental Management & 1 & \\
\hline Design Engineering & Others & 1 & \\
\hline \multirow{29}{*}{ Elsevier } & Applied Soft Computing & 1 & \\
\hline & Combustion and Flame & 1 & \\
\hline & Computer and Chemical Engineering & 1 & \\
\hline & Computers \& Industrial Engineering & 1 & \\
\hline & Energy & 5 & $3.7 \%$ \\
\hline & Energy Conversion and Management & 1 & $0.75 \%$ \\
\hline & Energy for Sustainable Development & 1 & $0.75 \%$ \\
\hline & Energy Policy & 2 & $1.5 \%$ \\
\hline & Energy Reports & 3 & $2.2 \%$ \\
\hline & Energy Strategy Reviews & 1 & $0.75 \%$ \\
\hline & Experts Systems with Applications & 1 & $0.75 \%$ \\
\hline & Heliyon & 2 & $1.5 \%$ \\
\hline & International Journal of Hydrogen Energy & 3 & $2.2 \%$ \\
\hline & International Journal of Production & 1 & $0.75 \%$ \\
\hline & $\begin{array}{l}\text { Economics } \\
\text { Journal of Air Transport Management }\end{array}$ & 1 & $0.75 \%$ \\
\hline & Journal of Cleaner Production & 17 & $12.7 \%$ \\
\hline & Journal of Energy Storage & 7 & $5.2 \%$ \\
\hline & Land Use Policy & 1 & \multirow{4}{*}{$4 \times 0.75=3 \%$} \\
\hline & Ocean and Coastal Management & 1 & \\
\hline & Ocean Engineering & 1 & \\
\hline & Procedia Manufacturing & 1 & \\
\hline & Renewable and sustainable energy Reviews & 9 & $6.7 \%$ \\
\hline & Renewable Energy & 7 & $5.2 \%$ \\
\hline & Sustainable Cities and Society & 3 & $2.2 \%$ \\
\hline & $\begin{array}{l}\text { Sustainable Energy Technologies and } \\
\text { Assessments }\end{array}$ & 5 & $3.7 \%$ \\
\hline & Sustainable Operations and Computers & 1 & \multirow{8}{*}{$10 \times 0.75=7.5 \%$} \\
\hline & Technological Forecasting \& Social Change & 1 & \\
\hline & Technological Forecasting and Social Change & 1 & \\
\hline & Thermal Science and Engineering Progress & 1 & \\
\hline \multirow{4}{*}{ IEEE } & $\begin{array}{l}\text { Environmental Science and Pollution } \\
\text { Research }\end{array}$ & 1 & \\
\hline & TRANSACTIONS ON ENGINEERING & 1 & \\
\hline & MANAGEMENT & 1 & \\
\hline & $\begin{array}{l}\text { Others } \\
\text { ICRERA }\end{array}$ & $\begin{array}{l}1 \\
1\end{array}$ & \\
\hline
\end{tabular}


Table 6. Cont.

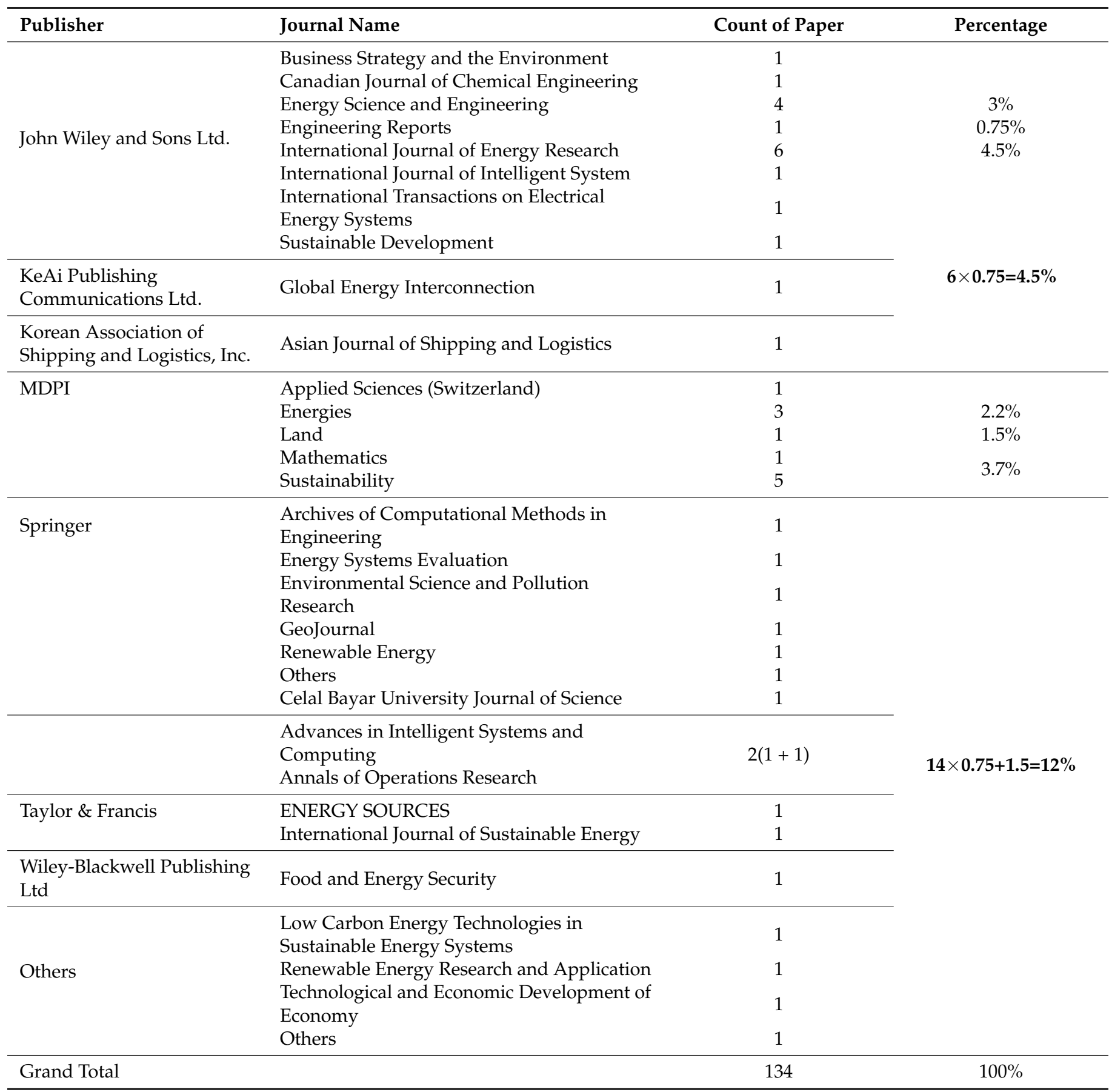

The study suggests that the authors have performed a wide range of research work in the Journal of Cleaner Production, in areas of energy facility location [102,103], energy source selection [113], energy system selection [48,65,94], decision analysis, [99], sustainability evaluation [96,98,124], and process optimization [63]. In this journal, for the energy system selection criteria, Angelo et al., (2018) [48] proposes an SFAHNP decision model to address the complexity and uncertainty involved in the clean technology selection process. This method first decomposes the problem into a hierarchical network structure, and then derives the probability distribution of the priority weights needed for ranking. Zhenfeng et al., (2018) performed a research study that allows multiple stakeholders to participate in decision making. They are also allowed to use linguistic variables to rate the alternatives and determine the weights of the evaluation criteria. Kumar et al.'s [63] study focused on 
determining the optimal processing conditions to minimize multi-performance features, such as surface roughness, roundness error, and run-out, in the thermal drilling of galvanized steel using the grey fuzzy logic technique. The implemented method combines the GRA with the FL technique, which allows the GFRG to be determined based on the GRC of each response. Rani et al. [65] designed and implemented the dioxide reforming of methane (CDRM) in her research, using divergence and entropy measures, VIKOR. The developed strategy successfully modeled a "real-world" environment, as experienced in the process industries. A flow term was introduced that served as a control element. In addition to this, the mathematical model of the reactor was modified to include time dependency for dynamicity.

Table 7 identifies the studies that have used sensitivity and/or comparative analysis to check the robustness of their findings and the system itself. The first column entails two analysis categories that have been in trend as per the present data analysis. The following column entails the indices of the research paper that has used either of the methods. Sensitivity analysis determines how many target variables have been affected, based on changes in input variables. This financial model is also referred to as "what-if" or "simulation analysis". It simulates results and predicts the outcome of a decision given a certain range of variables.

Table 7. Distribution of papers based on sensitive and comparative analysis.

\begin{tabular}{cccc}
\hline Analysis Type & Studies & Total & Percentage \\
\hline \multirow{3}{*}{ Sensitivity analysis } & {$[52,76,82,89,94,98,100,101$,} & & \\
& $103,106,122,124,131,133$, & 14 & $17.234 \%$ \\
Comparative analysis & $149,155,160,165,166]$ & & \\
& $\begin{array}{c}{[47,49,58,72,76,99,101,103,} \\
\text { 105,106,113] } \\
\text { Total }\end{array}$ & 12 & $14.815 \%$ \\
& 26 & $32.098 \%$ \\
\hline
\end{tabular}

(RQ 6) How many studies have performed comparative and sensitive analysis?

(RQ 7) How are papers distributed based on an application basis?

Table 8 identifies the distribution of studies based on several application classes. Energy facility location has been used as an application area for 27 research works, and constitutes $21 \%$ of the entirety. This application area further considers offshore wind farms, wind power plants, small hydropower plant location selection, nuclear power plant site selection, incineration plant site selection, hydrogen power plant site selection, windpowered pumped storage power plant site selection, the framework of photovoltaic hybrid projects as an area of study, and the output solution for site selection using a wide range of fuzzy sets. Some miscellaneous papers on several classes are in the following table.

Energy system selection, with 18 research studies, makes up 14\% of the entire survey. It classifies application areas into even more specific classes, which are composed of carbon nanotube synthesis methods, nutrient removal treatment technology options for municipal wastewater, low-carbon electricity sources, windfarm energy storage systems, energy storage systems, utilization of renewable energy sources, photovoltaic energy systems, renewable energy technology selection, regional hybrid energy systems, energy-driven desalination irrigation systems, thermal performance in the battery system, framework for photovoltaic power coupling hydrogen storage project, waste to energy technology selection, a framework for photovoltaic power coupling hydrogen storage project, optimal design of solar, wind, diesel-based RO (reverse osmosis) desalination integrating flow battery and pumped-hydro storage, and selection of new design gas carriers. Sustainability evaluation contributes to 24 research papers and further classifies the application areas into categories of solving renewable energy source selection problems, sustainable development goals, concentrated solar power, selection of the most appropriate casting gating system, optimization to sustainable energy technologies, sustainability performance index for ranking energy storage technologies, potential photovoltaic assessment, renewable energy- 
powered desalination systems, sustainability in energy system management in an emerging economy context, windfarm site selection, sustainable aviation fuel production pathways, sustainability conditions of small hydro plants, evaluation and selection of sustainable hydrogen production technology, and scheme selection of design for disassembly. Energy selection and energy source selection have been implemented in 11 articles, and further classify the application area into categories of structuring local energy policies, electricity or power generation, renewable energy selection for net-zero energy communities, evaluation, and selection of sustainable hydrogen production technology. The miscellaneous papers includes categories such as material selection pertaining to energy domain, energy utilization, efficiency evaluation, benefit evaluation screening, evaluation of options, sustainability, resource selection problem.

Table 8. Distribution of papers based on different applications in the CES domain.

\begin{tabular}{|c|c|c|c|}
\hline Applications & Studies & Total & Percentage \\
\hline $\begin{array}{l}\text { Energy Facility } \\
\text { Location }\end{array}$ & $\begin{array}{c}{[45,46,72,73,76,85,86,91,100,102,103} \\
107,110,119,127-129,137,139,140,147 \\
148,151,152,159,163,169]\end{array}$ & 27 & $21 \%$ \\
\hline $\begin{array}{l}\text { Energy Source } \\
\text { Selection }\end{array}$ & {$[47,49,59,66,113,126,133,149,156,160]$} & 10 & $8 \%$ \\
\hline $\begin{array}{l}\text { Energy System } \\
\text { Selection }\end{array}$ & $\begin{array}{c}{[48,56,58,65,71,79,81-} \\
83,89,94,95,97,101,106,122,130,162]\end{array}$ & 18 & $14 \%$ \\
\hline Decision Analysis & $\begin{array}{c}{[75,97,99,111,117,135,153,155,157} \\
165,167,169]\end{array}$ & 12 & $9 \%$ \\
\hline Strategy Selection & {$[60,64,118,123,133]$} & 7 & $6 \%$ \\
\hline $\begin{array}{l}\text { Sustainability } \\
\text { Evaluation }\end{array}$ & $\begin{array}{c}{[52,54,77,88,89,92,96,110,115,124-} \\
126,128,131,132,136,141- \\
143,145,154,159,161,166]\end{array}$ & 24 & $19 \%$ \\
\hline Forecasting & {$[62,87,102,119,120]$} & 5 & $4 \%$ \\
\hline Process Optimization & {$[63,70,93,121]$} & 4 & $3 \%$ \\
\hline Ranking & {$[80,89,105,130,138]$} & 5 & $4 \%$ \\
\hline Miscellaneous & $\begin{array}{c}{[61,74,84,90,112,114,144,146,150,168,} \\
170-174]\end{array}$ & 15 & $12 \%$ \\
\hline
\end{tabular}

$(R Q 8)$ What are the categories of renewable energy sources that have been considered in this study?

Table 9 shows the distribution of research work based on renewable energy resources. It classifies all the application purposes for a particular energy class into one. Some research studies use multiple renewable energy sources, and provide a classification amongst multiple renewable energy sources to choose the best amongst them. Wind energy has been part of 15 research studies and constitutes $12 \%$ of the entire study. The segregation includes onshore, offshore, horizontal blades, vertical blades, and even wind farm site selection in one category. Based on the region, it spans over China, Vietnam, Iran, Turkey, and South Africa; while China has the majority of wind energy-related research. Solar energy, with seven research works, contributed to $8.642 \%$ of the study, and was performed in Chile, Vietnam, Pakistan, Iran, China, and Taiwan. Iran contributes the majority of the research in solar energy. It has been studied in India, China, the United Kingdom, and Taiwan, with China contributing the most to the study. It has also been studied in Iran, Singapore, Pakistan, and Brazil.

Figure 2 provides the distribution of articles considered year-wise in this review study under the CES field. The authors concentrated on the window from 2018 to 2021, and paid much attention to the last two years of CES research. It becomes substantial for the research community to clearly understand the trend and the direction of future research in the CES field. Some interesting challenges in the CES field that need further exploration from the research community are also discussed in this review paper, to give insights into future research in the CES field. 
Table 9. Distribution of studies based on the prominent renewable energy source.

\begin{tabular}{cccc}
\hline Renewable Energy & Studies & Total & Percentage \\
\hline Wind Energy & {$[45,46,58,74,86,91,100,107$,} & 15 & $12 \%$ \\
Solar Energy & {$[10,119,120,131,141,144,146]$} & & $8 \%$ \\
Hydrogen Energy & {$[54,61,71,92,99,103,106,138$,} & 10 & $4 \%$ \\
Nuclear & {$[85,97,105,106,126]$} & 5 & $2 \%$ \\
Hydro Energy & {$[73,118,121]$} & 3 & $2 \%$ \\
\hline
\end{tabular}

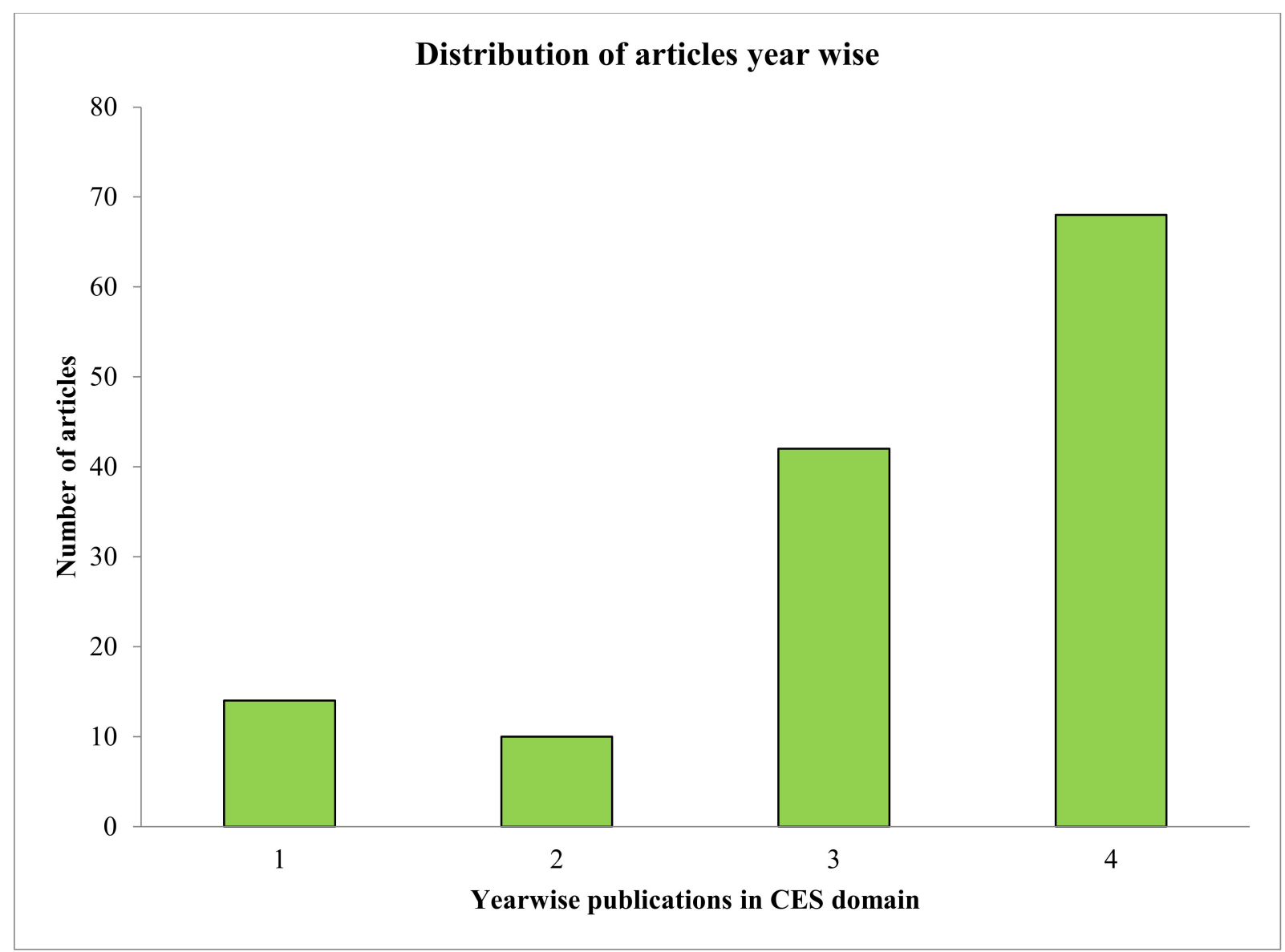

Figure 2. Year-wise publications of articles (X-axis-1 is 2018,2 is 2019,3 is 2020, 4 is 2021).

\subsection{Challenges in CES Evaluation for Future Research}

This section discusses the inferences gained from the review process, and presents future directions for research in the CES field.

- The tabulations clearly show that fuzzy-based approaches involving rating data transformation to fuzzy variants are popular in CES selection. Tables 1 and 3 provide evidence to the claim.

- Another notable inference is that the authors commonly adopt AHP, VIKOR, and TOPSIS under fuzzy contexts (from Table 2) to gain rational decisions on the CES field. Variants of AHP are also commonly adopted. Researchers recently adopted integrated schemes where fuzzy set ideas are integrated with machine learning methods, which gained a lot of attention in the CES field. The net contribution from the review process is observed to be close to $50 \%$. 
- Furthermore, it can be inferred that the triangular fuzzy number is a popular fuzzy variant adopted by researchers as preference information in the CES field. The orthopair variants constitute around $32 \%$, indicating the popularity of numeric decision making in the CES domain.

- Contributions from China and India to the field of CES are around $44 \%$, with a prime focus on integrated decision approaches under the fuzzy context (from Table 4). The selection of apt energy sources for the demand satisfaction and location identification of plant construction are interesting applications that are explored by the countries' researchers.

- Elsevier has dominated publication in the CES field, with popular journals, such as the Journal of Cleaner Production, Energy, and Renewable and Sustainable Reviews, that attract readership in the CES field (from Table 5). These journals follow a rigorous review process to ensure quality research is given to their readers.

Based on these observations, certain challenges that need to be addressed in the future are listed below:

- Certain research has started with linguistic decision models for the CES field, which could be further enhanced by bringing sophisticated linguistic models for data acquisition from agents involved in the CES domain.

- Human intervention causes biases and inaccuracies in the decision process. Therefore, models must be developed with less human intervention and an acceptable level of complexity.

- $\quad$ Research relating to the integration of machine learning concepts with decision models has begun in the CES domain. Further exploration is required to develop approaches to solve large-scale decision problems better, which is lacking at the present stage.

- Finally, researchers must work on creating usable products that aid policymakers in making choices in critical situations.

\section{Conclusions}

This review article aims to identify the extent to which decision models are used in the CES field under different fuzzy contexts. To extend the review of different researchers, this paper considers a window of 2018 to 2021 . Around 129 articles are reviewed under the different perceptions that constitute eight research questions. These research questions adhere to the bibliometric theme, and the responses to the questions add high value to further research in the CES field. Three significant publishers, viz., Elsevier, Wiley, and Springer, are considered for data collection, and the journals are all indexed in the Web of Science ISI repository. Popular journals, such as the Journal of Cleaner Production, Energy, and Renewable and Sustainable Reviews, are prevalent in attracting readership in the CES field. AHP, VIKOR, and TOPSIS are usually the employed methods under fuzzy contexts. Researchers recently also proposed integrated approaches using fuzzy logic and machine learning methods, which attracted strong interest in the CES field. The review adds to the literature studies that had already been conducted by considering the window of 2018 to 2021, so that the research community can gain sufficient knowledge on the current scenario in the CES field. Our research provides intuitive information on the trend line of CES evaluation, as well as providing evidence on the appropriate journals for the CES field, the nation-wise contribution to the field, and so on.

The authors organized the articles into eight research questions to obtain valuable knowledge from year-wise publications on the distribution of articles from the diverse point of views in CES. The review paper acts as a base for other researchers to build their new research ideas and carry forward reviews in the years to come. These research questions would surely help the research community to understand the CES field better from diverse perceptions/contexts. As a future direction for review, new questions can be developed, along with responses to these questions. In the future, reviews on other decision applications such as in Refs. [180-183]; specific energy sources can also aid researchers in the field of study. 
Author Contributions: Conceptualization: A.K.P., R.K., D.P.; data Collection: A.K.P., R.K., S.K.; data refining/cleaning: A.K.P., R.K., A.M., D.P., S.K.; RQ formation and response building: A.K.P., R.K., A.M., K.S.R., F.C.; presentation enhancement: A.M., D.P., S.K.; article writing: A.K.P., R.K., S.K.; fine-tuning content: D.P., K.S.R., F.C.; language editing: K.S.R., F.C. All authors have read and agreed to the published version of the manuscript.

Funding: This research received no external funding.

Institutional Review Board Statement: Not applicable.

Informed Consent Statement: Not applicable.

Data Availability Statement: Not applicable.

Conflicts of Interest: The authors declare no conflict of interest.

\section{Appendix A}

Table A1. List of abbreviations and expansions.

\begin{tabular}{|c|c|}
\hline Abbreviation & Expansion \\
\hline AHP & Analytical Hierarchy Process \\
\hline ANP & Analytic Network Process \\
\hline PSO & Particle Swarm Optimization \\
\hline $\mathrm{MOO}$ & Multi-Objective Optimization \\
\hline VIKOR & VIsekriterijumska Optimizacija I Kompromisno Resenje \\
\hline WSM & Weighted Sum Method \\
\hline TOPSIS & $\begin{array}{l}\text { Technique for Order of Preference by Similarity to Ideal } \\
\text { Solution }\end{array}$ \\
\hline MOPSO & Multi-Objective Particle Swarm Optimization \\
\hline MAUT & Multi-Attribute Utility Theory \\
\hline SVR & Support Vector Regression \\
\hline MLR & Multiple Linear Regression \\
\hline GA & Genetic Algorithm \\
\hline RF & Random Forest \\
\hline WASPAS & Weighted Aggregated Sum Product Assessment \\
\hline INRM & Influential Network Relationship Map \\
\hline MAGDM & Multi-Attribute Group Decision Making \\
\hline MCGDM & Multi-Criteria Group Decision Making \\
\hline MODA & Multi-Objective Decision Approaches \\
\hline MGU & Maximum Group Utility \\
\hline LSTM-CNN & Long Short Term Memory-Convolutional Neural Network \\
\hline ARAS & Additive Ratio Assessment \\
\hline SWARA & Stepwise Weight Assessment Ratio Analysis \\
\hline CRITIC & Criteria Index Correlation \\
\hline LBWA & Level Based Weight Assessment \\
\hline IDOCRIW & Integrated Determination of Objective Criteria Weights \\
\hline CODAS & Combinative Distance-based Assessment \\
\hline EDAS & Evaluation Based on Distance from Average Solution \\
\hline MOOSRA & Multi-Objective Optimization based on Simple Ratio Analysis \\
\hline MOGA & Multi-Objective Genetic Algorithm \\
\hline NSGA-II & Nondominated Sorting Genetic Algorithm II \\
\hline MPC & Model Predictive Control \\
\hline MULTIMOORA & Multiple Objective Optimization based on Ratio Analysis \\
\hline DEMATEL & Decision-Making Trail and Evaluation Laboratory \\
\hline PROMETHEE & $\begin{array}{l}\text { Preference Ranking Organization Method for Enrichment of } \\
\text { Evaluations }\end{array}$ \\
\hline MARCOS & $\begin{array}{l}\text { Measurement Alternatives and Ranking according to } \\
\text { Copromise Solution }\end{array}$ \\
\hline IDM & Investment Decision Making \\
\hline MEE & Matter Element Extension \\
\hline $\mathrm{ECP}$ & Expected Constraint Programming \\
\hline
\end{tabular}


Table A1. Cont.

\begin{tabular}{|c|c|}
\hline Abbreviation & Expansion \\
\hline SAW & Simple Additive Weighting \\
\hline FA & Firefly Algorithm \\
\hline EVAMIX & Evaluation of Mixed \\
\hline DDSM & Data-Driven Screening Model \\
\hline ELECTRE & $\begin{array}{l}\text { Elimination Et Choix Traduisant la Realité (ELimination Et } \\
\text { Choice Translating Reality) }\end{array}$ \\
\hline ANN & Artificial Neural Network \\
\hline MPPT & Maximum Power Point Tracking \\
\hline SA & Simulated Annealing \\
\hline BWM & Best-Worst Method \\
\hline COPRAS & Complex Proportional Assessment \\
\hline IRS & Ideal Referential Solution \\
\hline GRA & Grey Relational Analysis \\
\hline SW & Sum Weighted \\
\hline FSM & Fuzzy Satisfaction Method \\
\hline HFL & Hesitant Fuzzy Linguistic \\
\hline IVF & Interval-Valued Fuzzy \\
\hline TRI-FUZZY NUMBER & Triangular Fuzzy Number \\
\hline TRAP-FUZZY NUMBER & Trapezoidal Fuzzy Number \\
\hline PYTH-FUZZY NUMBER & Pythagorean Fuzzy Number \\
\hline ANFIS & Adaptive Neural Fuzzy Inference System \\
\hline I2TLIFN & Interval 2 Tuple Linguistic Fuzzy Number \\
\hline SFAHNP & Stochastic Fuzzy Analytic Hierarchical Network Process \\
\hline FUZZY-MAPM & Fuzzy Multi-Attribute Preference Model \\
\hline FUZZY MOD & Fuzzy Multi-Objective Decision \\
\hline FEA & Fuzzy Expert Approach \\
\hline ICFHHA & Intuitionistic Cubic Fuzzy Hamacher Hybrid Averaging \\
\hline ICFHOWA & Intuitionistic Cubic Fuzzy Hamacher Weighted Averaging \\
\hline ICFS & Intuitionistic Cubic Fuzzy Set \\
\hline LINEAR PROG & Linear Programming \\
\hline TIFH & Trapezoidal Intuitionistic Fuzzy Number \\
\hline FUCOM & Full Consistency Method \\
\hline DEA & Data Envelopment Analysis \\
\hline IQ-ROFPWMM & Interval Q-Rung Orthopair Weighted Power Muirhead Mean \\
\hline A-SVN-DM & Aggregated Single-Valued Neutrosophic Decision Matrix \\
\hline FAHP & Fuzzy AHP \\
\hline CoCoSo & Combined Compromise Solution \\
\hline $\mathrm{CM}$ & Compromise Measure (CM) \\
\hline DEs & Decision experts \\
\hline EWP & Exponentially Weighted Product \\
\hline FS & Fuzzy Set \\
\hline GHG & Greenhouse Gas \\
\hline GUM & Group Utility Measure \\
\hline IFS & Intuitionistic Fuzzy Set \\
\hline IRM & Individual Regret Measure \\
\hline LVs & Linguistic Values \\
\hline MCDM & Multi-criteria Decision Making \\
\hline NS & Neutrosophic Set \\
\hline RES & Renewable Energy Source \\
\hline SVNS & Single-Valued Neutrosophic Set \\
\hline SVN & Single-Valued Neutrosophic \\
\hline SVN-SWARA-CoCoSo & Single-Valued Neutrosophic-SWARA-CoCoSo \\
\hline SVN-TOPSIS & Single-Valued Neutrosophic TOPSIS \\
\hline SVN-VIKOR & Single-Valued Neutrosophic VIKOR \\
\hline SVN-WASPAS & Single-Valued Neutrosophic WASPAS \\
\hline SAW & Simple Additive Weighting \\
\hline WEEE & Waste Electrical and Electronic Equipment \\
\hline WSM & Weighted Sum Model \\
\hline WPM & Weighted Product Model \\
\hline
\end{tabular}




\section{References}

1. Reddy, S.; Painuly, J.P. Diffusion of renewable energy technologies-Barriers and stakeholders' perspectives. Renew. Energy 2004, 29, 1431-1447. [CrossRef]

2. Ourbak, T.; Magnan, A.K. The Paris Agreement and climate change negotiations: Small Islands, big players. Reg. Environ. Chang. 2018, 18, 2201-2207. [CrossRef]

3. Yoro, K.O.; Daramola, M.O. CO2 Emission Sources, Greenhouse Gases, and the Global Warming Effect; Elsevier Inc.: Amsterdam, The Netherlands, 2020; ISBN 9780128196571. [CrossRef]

4. Ilbahar, E.; Cebi, S.; Kahraman, C. A state-of-the-art review on multi-attribute renewable energy decision making. Energy Strat. Rev. 2019, 25, 18-33. [CrossRef]

5. Indragandhi, V.; Subramaniyaswamy, V.; Logesh, R. Resources, configurations, and soft computing techniques for power management and control of PV/wind hybrid system. Renew. Sustain. Energy Rev. 2017, 69, 129-143. [CrossRef]

6. Liao, C.; Erbaugh, J.T.; Kelly, A.C.; Agrawal, A. Clean energy transitions and human well-being outcomes in Lower and Middle Income Countries: A systematic review. Renew. Sustain. Energy Rev. 2021, 145, 111063. [CrossRef]

7. Pillai, I.R.; Banerjee, R. Renewable energy in India: Status and potential. Energy 2009, 34, 970-980. [CrossRef]

8. Mardani, A.; Zavadskas, E.K.; Khalifah, Z.; Zakuan, N.; Jusoh, A.; Nor, K.M.; Khoshnoudi, M. A review of multi-criteria decision-making applications to solve energy management problems: Two decades from 1995 to 2015. Renew. Sustain. Energy Rev. 2017, 71, 216-256. [CrossRef]

9. Kumar, A.; Sah, B.; Singh, A.R.; Deng, Y.; He, X.; Kumar, P.; Bansal, R. A review of multi criteria decision making (MCDM) towards sustainable renewable energy development. Renew. Sustain. Energy Rev. 2017, 69, 596-609. [CrossRef]

10. Strantzali, E.; Aravossis, K. Decision making in renewable energy investments: A review. Renew. Sustain. Energy Rev. 2016, 55, 885-898. [CrossRef]

11. Siksnelyte-Butkiene, I.; Zavadskas, E.K.; Streimikiene, D. Multi-criteria decision-making (MCDM) for the assessment of renewable energy technologies in a household: A review. Energies 2020, 13, 1164. [CrossRef]

12. Olson, D. Comparison of weights in TOPSIS models. Math. Comput. Model. 2004, 40, 721-727. [CrossRef]

13. Kao, C. Weight determination for consistently ranking alternatives in multiple criteria decision analysis. Appl. Math. Model. 2010, 34, 1779-1787. [CrossRef]

14. Saaty, T.L. Decision making with the analytic hierarchy process. Int. J. Serv. Sci. 2008, 1, 83. [CrossRef]

15. Saaty, T.L.; Vargas, L.G. The analytic network process. Decis. Mak. Anal. Netw. Process 2013, 195, 1-40. [CrossRef]

16. Emrouznejad, A.; Marra, M. The state of the art development of AHP (1979-2017): A literature review with a social network analysis. Int. J. Prod. Res. 2017, 55, 6653-6675. [CrossRef]

17. Russo, R.; Camanho, R. Criteria in AHP: A systematic review of literature. Procedia Comput. Sci. 2015, 55, 1123-1132. [CrossRef]

18. Namdari, A.; Li, Z. A review of entropy measures for uncertainty quantification of stochastic processes. Adv. Mech. Eng. 2019, 11, 1-14. [CrossRef]

19. Kumar, R.; Singh, S.; Bilga, P.S.; Jatin, K.; Singh, J.; Singh, S.; Scutaru, M.-L.; Pruncu, C.I. Revealing the benefits of entropy weights method for multi-objective optimization in machining operations: A critical review. J. Mater. Res. Technol. 2021, 10, 1471-1492. [CrossRef]

20. Diakoulaki, D.; Mavrotas, G.; Papayannakis, L. Determining objective weights in multiple criteria problems: The critic method. Comput. Oper. Res. 1995, 22, 763-770. [CrossRef]

21. Žižović, M.; Miljković, B.; Marinković, D. Objective methods for determining criteria weight coefficients: A modification of the CRITIC method. Decis. Mak. Appl. Manag. Eng. 2020, 3, 149-161. [CrossRef]

22. Keršulienè, V.; Zavadskas, E.K.; Turskis, Z. Selection of rational dispute resolution method by applying new step-wise weight assessment ratio analysis (SWARA). J. Bus. Econ. Manag. 2010, 11, 243-258. [CrossRef]

23. Mardani, A.; Nilashi, M.; Zakuan, N.; Loganathan, N.; Soheilirad, S.; Saman, M.Z.M.; Ibrahim, O. A systematic review and meta-Analysis of SWARA and WASPAS methods: Theory and applications with recent fuzzy developments. Appl. Soft Comput. 2017, 57, 265-292. [CrossRef]

24. Zavadskas, E.K.; Turskis, Z.; Tamošaitienè, J. Multicriteria selection of project managers by applying grey criteria. Technol. Econ. Dev. Econ. 2008, 14, 462-477. [CrossRef]

25. Chakraborty, S.; Zavadskas, E.K. Applications of WASPAS method in manufacturing decision making. Informatica 2014, 25, 1-20. [CrossRef]

26. Stefano, N.M.; Filho, N.C.; Vergara, L.G.L.; Da Rocha, R.U.G. COPRAS (Complex proportional assessment): State of the art research and its applications. IEEE Lat. Am. Trans. 2015, 13, 3899-3906. [CrossRef]

27. Opricovic, S.; Tzeng, G.-H. Compromise solution by MCDM methods: A comparative analysis of VIKOR and TOPSIS. Eur. J. Oper. Res. 2004, 156, 445-455. [CrossRef]

28. Jigeesh, N.; Joseph, D.; Yadav, S.K. A review on industrial applications of TOPSIS approach. Int. J. Serv. Oper. Manag. 2018, 30, 23. [CrossRef]

29. Behzadian, M.; Otaghsara, S.K.; Yazdani, M.; Ignatius, J. A state-of the-art survey of TOPSIS applications. Expert Syst. Appl. 2012, 39, 13051-13069. [CrossRef]

30. Shukla, A.; Agarwal, P.; Rana, R.; Purohit, R. Applications of TOPSIS algorithm on various manufacturing processes: A Review. Mater. Today Proc. 2017, 4, 5320-5329. [CrossRef] 
31. Mardani, A.; Zavadskas, E.K.; Govindan, K.; Senin, A.A.; Jusoh, A. VIKOR technique: A systematic review of the state of the art literature on methodologies and applications. Sustainability 2016, 8, 37. [CrossRef]

32. Gul, M.; Erkan, C.; Nezir, A.; Gumus, A.; Ali, G. A state of the art literature review of VIKOR and its fuzzy extensions on applications. Appl. Soft Comput. 2016, 46, 60-89. [CrossRef]

33. Tomić, V.; Marinković, Z.; Janošević, D. PROMETHEE method implementation with multi-criteria decisions. Mech. Eng. 2011, 9 , 193-202.

34. Figueria, J.R.; Greco, S.; Roy, B. Electre methods with interaction between criteria: An extension of concordance index. Eur. J. Oper. Res. 2009, 199, 478-495. [CrossRef]

35. Behzadian, M.; Kazemzadeh, R.; Albadvi, A.; Aghdasi, M. PROMETHEE: A comprehensive literature review on methodologies and applications. Eur. J. Oper. Res. 2010, 200, 198-215. [CrossRef]

36. Govindan, K.; Jepsen, M.B. ELECTRE: A comprehensive literature review on methodologies and applications. Eur. J. Oper. Res. 2016, 250, 1-29. [CrossRef]

37. Zadeh, L. A Fuzzy logic systems: Origin, concepts, and trends. Science 2004, 80, 16-18.

38. Atanassov, K. Intuitionistic fuzzy sets. Fuzzy Sets Syst. 1986, 20, 87-96. [CrossRef]

39. Yager, R.R. Pythagorean membership grades in multicriteria decision making. IEEE Trans. Fuzzy Syst. 2014, $22,958-965$. [CrossRef]

40. Torra, V. Hesitant fuzzy sets. Int. J. Intell. Syst. 2010, 25, 529-539. [CrossRef]

41. Xu, Z.; Zhao, N. Information fusion for intuitionistic fuzzy decision making: An overview. Inf. Fusion 2016, 28, 10-23. [CrossRef]

42. Xu, Z. Intuitionistic fuzzy aggregation operators. IEEE Trans. Fuzzy Syst. 2007, 15, 1179-1187. [CrossRef]

43. Peng, X.; Selvachandran, G. Pythagorean fuzzy set: State of the art and future directions. Artif. Intell. Rev. 2019, 52, 1873-1927. [CrossRef]

44. Rodríguez, R.M.; Martínez, L.; Torra, V.; Xu, Z.S.; Herrera, F. Hesitant fuzzy sets: State of the art and future directions. Int. J. Intell. Syst. 2014, 29, 495-524. [CrossRef]

45. Wu, B.; Yip, T.L.; Xie, L.; Wang, Y. A fuzzy-MADM based approach for site selection of offshore wind farm in busy waterways in China. Ocean Eng. 2018, 168, 121-132. [CrossRef]

46. Wang, C.-N.; Huang, Y.-F.; Chai, Y.-C.; Nguyen, V.T. A multi-criteria decision making (MCDM) for renewable energy plants location selection in vietnam under a fuzzy environment. Appl. Sci. 2018, 8, 2069. [CrossRef]

47. Büyüközkan, G.; Karabulut, H.Y.; Mukul, E. A novel renewable energy selection model for United Nations' sustainable development goals. Energy 2018, 165, 290-302. [CrossRef]

48. Promentilla, M.A.B.; Janairo, J.I.; Yu, D.E.C.; Pausta, C.M.J.; Beltran, A.B.; Huelgas-Orbecido, A.P.; Tapia, J.F.; Aviso, K.B.; Tan, R.R. A stochastic fuzzy multi-criteria decision-making model for optimal selection of clean technologies. J. Clean. Prod. 2018, 183, 1289-1299. [CrossRef]

49. Lee, H.C.; Chang, C. Ter Comparative analysis of MCDM methods for ranking renewable energy sources in Taiwan. Renew. Sustain. Energy Rev. 2018, 92, 883-896. [CrossRef]

50. Ghimire, L.P.; Kim, Y. An analysis on barriers to renewable energy development in the context of Nepal using AHP. Renew. Energy 2018, 129, 446-456. [CrossRef]

51. Development, E.; Chatterjee, K.; Kar, S. A Multi criteria decision making for renewable energy selection using z numbers. Technol. Econ. Dev. Econ. 2018, 24, 739-764.

52. Chen, L.; Ren, J. Multi-attribute sustainability evaluation of alternative aviation fuels based on fuzzy ANP and fuzzy grey relational analysis. J. Air Transp. Manag. 2018, 68, 176-186. [CrossRef]

53. Boran, F.E. A new approach for evaluation of renewable energy resources: A case of Turkey. Energy Sources Part B Econ. Plan. Policy 2018, 13, 196-204. [CrossRef]

54. Simsek, Y.; Watts, D.; Escobar, R. Sustainability evaluation of concentrated solar power (CSP) projects under clean development mechanism (CDM) by using multi criteria decision method (MCDM). Renew. Sustain. Energy Rev. 2018, 93, 421-438. [CrossRef]

55. Sehatpour, M.-H.; Kazemi, A. Sustainable fuel portfolio optimization: Integrated fuzzy multi-objective programming and multi-criteria decision making. J. Clean. Prod. 2018, 176, 304-319. [CrossRef]

56. Li, L.; Liu, P.; Li, Z.; Wang, X. A multi-objective optimization approach for selection of energy storage systems. Comput. Chem. Eng. 2018, 115, 213-225. [CrossRef]

57. Alizadeh, R.; Soltanisehat, L.; Lund, P.D.; Zamanisabzi, H. Improving renewable energy policy planning and decision-making through a hybrid MCDM method. Energy Policy 2020, 137, 111174. [CrossRef]

58. Liu, J.; Wei, Q.; Huang, J.; Zhou, W.; Yu, J. Collaboration strategy and optimization model of wind farm-hybrid energy storage system for mitigating wind curtailment. Energy Sci. Eng. 2019, 7, 3255-3273. [CrossRef]

59. Rosso-Cerón, A.; Kafarov, V.; Latorre-Bayona, G.; Quijano-Hurtado, R. A novel hybrid approach based on fuzzy multi-criteria decision-making tools for assessing sustainable alternatives of power generation in San Andrés Island. Renew. Sustain. Energy Rev. 2019, 110, 159-173. [CrossRef]

60. Tarybakhsh, M.R.; Sadeghi, M.T.; Assareh, M. Development of a data-driven fuzzy screening model for enhanced oil recovery methods using an adaptive weighting system. Can. J. Chem. Eng. 2019, 97, 3035-3051. [CrossRef]

61. Mostafaeipour, A.; Sedeh, A.S. Investigation of solar energy utilization for production of hydrogen and sustainable chemical fertilizer: A case study. Int. J. Energy Res. 2019, 43, 8314-8336. [CrossRef] 
62. Deo, R.C.; Downs, N.J.; Adamowski, J.F.; Parisi, A.V. Adaptive neuro-fuzzy inference system integrated with solar zenith angle for forecasting sub-tropical photosynthetically active radiation. Food Energy Secur. 2018, 8, e00151. [CrossRef]

63. Kumar, R.; Hynes, N.R.J.; Pruncu, C.I.; Sujana, J.A.J. Multi-objective optimization of green technology thermal drilling process using grey-fuzzy logic method. J. Clean. Prod. 2019, 236, 236. [CrossRef]

64. Essien, E.; Ibrahim, H.; Mehrandezh, M.; Idem, R. Adaptive neuro-fuzzy inference system (ANFIS)-based model predictive control (MPC) for carbon dioxide reforming of methane (CDRM) in a plug flow tubular reactor for hydrogen production. Therm. Sci. Eng. Prog. 2019, 9, 148-161. [CrossRef]

65. Rani, P.; Mishra, A.R.; Pardasani, K.R.; Mardani, A.; Liao, H.; Streimikiene, D. A novel VIKOR approach based on entropy and divergence measures of Pythagorean fuzzy sets to evaluate renewable energy technologies in India. J. Clean. Prod. 2019, 238, 117936. [CrossRef]

66. Karunathilake, H.; Hewage, K.; Mérida, W.; Sadiq, R. Renewable energy selection for net-zero energy communities: Life cycle based decision making under uncertainty. Renew. Energy 2019, 130, 558-573. [CrossRef]

67. Krishankumar, R.; Ravichandran, K.S.; Kar, S.; Cavallaro, F.; Zavadskas, E.K.; Mardani, A. Scientific decision framework for evaluation of renewable energy sources under Q-rung orthopair fuzzy set with partially known weight information. Sustainability 2019, 11, 4202. [CrossRef]

68. Krishankumar, R.; Mishra, A.R.; Ravichandran, K.S.; Peng, X.; Zavadskas, E.K.; Cavallaro, F.; Mardani, A. A group decision framework for renewable energy source selection under interval-valued probabilistic linguistic term set. Energies 2020, 13, 986. [CrossRef]

69. Rani, P.; Mishra, A.R.; Mardani, A.; Cavallaro, F.; Alrasheedi, M.; Alrashidi, A. A novel approach to extended fuzzy TOPSIS based on new divergence measures for renewable energy sources selection. J. Clean. Prod. 2020, 257, 120352. [CrossRef]

70. Yousef, B.A.A.; Rezk, H.; Abdelkareem, M.A.; Olabi, A.G.; Nassef, A.M. Fuzzy modeling and particle swarm optimization for determining the optimal operating parameters to enhance the bio-methanol production from sugar cane bagasse. Int. J. Energy Res. 2020, 44, 8964-8973. [CrossRef]

71. Asif, R.M.; Rehman, A.U.; Rehman, S.U.; Arshad, J.; Hamid, J.; Sadiq, M.T.; Tahir, S. Design and analysis of robust fuzzy logic maximum power point tracking based isolated photovoltaic energy system. Eng. Rep. 2020, 2, 2. [CrossRef]

72. Abdullah, S.; Aslam, M. New multicriteria group decision support systems for small hydropower plant locations selection based on intuitionistic cubic fuzzy aggregation information. Int. J. Intell. Syst. 2020, 35, 983-1020. [CrossRef]

73. Wu, Y.; Liu, F.; Huang, Y.; Xu, C.; Zhang, B.; Ke, Y.; Jia, W. A two-stage decision framework for inland nuclear power plant site selection based on GIS and type-2 fuzzy PROMETHEE II: Case study in China. Energy Sci. Eng. 2020, 8, 1941-1961. [CrossRef]

74. Okokpujie, I.; Okonkwo, U.; Bolu, C.; Ohunakin, O.; Agboola, M.; Atayero, A. Implementation of multi-criteria decision method for selection of suitable material for development of horizontal wind turbine blade for sustainable energy generation. Heliyon 2020, 6, e03142. [CrossRef] [PubMed]

75. Guðlaugsson, B.; Fazeli, R.; Gunnarsdóttir, I.; Davidsdottir, B.; Stefansson, G. Classification of stakeholders of sustainable energy development in Iceland: Utilizing a power-interest matrix and fuzzy logic theory. Energy Sustain. Dev. 2020, 57, 168-188. [CrossRef]

76. Luo, C.; Ju, Y.; Gonzalez, E.D.R.S.; Dong, P.; Wang, A. The waste-to-energy incineration plant site selection based on hesitant fuzzy linguistic best-worst method ANP and double parameters TOPSIS approach: A case study in China. Energy 2020, 211, 118564. [CrossRef]

77. Papanikolaou, M.; Pagone, E.; Salonitis, K.; Jolly, M. Sustainability-based evaluation of casting gating systems: A multi-criteria decision-making approach. Procedia Manuf. 2020, 43, 704-711. [CrossRef]

78. Wang, Y.; Xu, L.; Solangi, Y.A. Strategic renewable energy resources selection for Pakistan: Based on SWOT-Fuzzy AHP approach. Sustain. Cities Soc. 2020, 52, 101861. [CrossRef]

79. Kamari, M.L.; Isvand, H.; Nazari, M.A. Applications of multi-criteria decision-making (MCDM) methods in renewable energy development: A review. Renew. Energy Res. Appl. 2020, 1, 47-54.

80. Alkan, Ö.; Albayrak, Ö.K. Ranking of renewable energy sources for regions in Turkey by fuzzy entropy based fuzzy COPRAS and fuzzy MULTIMOORA. Renew. Energy 2020, 162, 712-726. [CrossRef]

81. Song, X.; Zhao, R.; De, G.; Wu, J.; Shen, H.; Tan, Z.; Liu, J. A fuzzy-based multi-objective robust optimization model for a regional hybrid energy system considering uncertainty. Energy Sci. Eng. 2020, 8, 926-943. [CrossRef]

82. Hu, K.; Tan, Q.; Zhang, T.; Wang, S. Assessing technology portfolios of clean energy-driven desalination-irrigation systems with interval-valued intuitionistic fuzzy sets. Renew. Sustain. Energy Rev. 2020, 132, 109950. [CrossRef]

83. Karaşan, A.; Gündoğdu, F.K.; Kahraman, C. Pythagorean fuzzy AHP method for the selection of the most appropriate clean energy technology. In Advances in Intelligent Systems and Computing; Springer: New York, NY, USA, 2020; Volume 1029, pp. 879-887.

84. Ikram, M.; Zhang, Q.; Sroufe, R. Developing integrated management systems using an AHP-Fuzzy VIKOR approach. Bus. Strat. Environ. 2020, 29, 2265-2283. [CrossRef]

85. Guleria, A.; Bajaj, R.K. A robust decision making approach for hydrogen power plant site selection utilizing (R, S)-norm pythagorean fuzzy information measures based on VIKOR and TOPSIS method. Int. J. Hydrogen Energy 2020, 45, 18802-18816. [CrossRef] 
86. Ahmadi, S.H.R.; Noorollahi, Y.; Ghanbari, S.; Ebrahimi, M.; Hosseini, H.; Foroozani, A.; Hajinezhad, A. Hybrid fuzzy decision making approach for wind-powered pumped storage power plant site selection: A case study. Sustain. Energy Technol. Assess. 2020, 42, 100838. [CrossRef]

87. Li, Y.; He, Y.; Zhang, M. Prediction of Chinese energy structure based on convolutional neural network-long short-term memory (CNN-LSTM). Energy Sci. Eng. 2020, 8, 2680-2689. [CrossRef]

88. Arriola, E.R.; Ubando, A.T.; Chen, W. A bibliometric review on the application of fuzzy optimization to sustainable energy technologies. Int. J. Energy Res. 2020, 22. [CrossRef]

89. Albawab, M.; Ghenai, C.; Bettayeb, M.; Janajreh, I. Sustainability Performance index for ranking energy storage technologies using multi-criteria decision-making model and hybrid computational method. J. Energy Storage 2020, 32, 101820. [CrossRef]

90. Wang, D.; Yu, J.; Liu, B.; Long, C.; Chen, P.; Chong, Z. Integrated energy efficiency evaluation of a multi-source multi-load desalination micro-energy network. Glob. Energy Interconnect. 2020, 3, 128-139. [CrossRef]

91. Deveci, M.; Özcan, E.; John, R.; Covrig, C.-F.; Pamucar, D. A study on offshore wind farm siting criteria using a novel intervalvalued fuzzy-rough based Delphi method. J. Environ. Manag. 2020, 270, 110916. [CrossRef] [PubMed]

92. Aryanfar, A.; Gholami, A.; Pourgholi, M.; Shahroozi, S.; Zandi, M.; Khosravi, A. Multi-criteria photovoltaic potential assessment using fuzzy logic in decision-making: A case study of Iran. Sustain. Energy Technol. Assess. 2020, 42, 100877. [CrossRef]

93. Rivera-Niquepa, J.D.; De Oliveira-De Jesus, P.M.; Castro-Galeano, J.C.; Hernández-Torres, D. Planning stand-alone electricity generation systems, a multiple objective optimization and fuzzy decision making approach. Heliyon 2020, 6, e03534. [CrossRef]

94. Ali, T.; Chiu, Y.-R.; Aghaloo, K.; Nahian, A.J.; Ma, H. Prioritizing the existing power generation technologies in Bangladesh's clean energy scheme using a hybrid multi-criteria decision making model. J. Clean. Prod. 2020, 267, 121901. [CrossRef]

95. Afzal, A.; Ramis, M. Multi-objective optimization of thermal performance in battery system using genetic and particle swarm algorithm combined with fuzzy logics. J. Energy Storage 2020, 32, 101815. [CrossRef]

96. Xu, D.; Ren, J.; Dong, L.; Yang, Y. Portfolio selection of renewable energy-powered desalination systems with sustainability perspective: A novel MADM-based framework under data uncertainties. J. Clean. Prod. 2020, 275, 124114. [CrossRef]

97. Wu, Y.; Wu, C.; Zhou, J.; He, F.; Xu, C.; Zhang, B.; Zhang, T. An investment decision framework for photovoltaic power coupling hydrogen storage project based on a mixed evaluation method under intuitionistic fuzzy environment. J. Energy Storage 2020, 30, 101601. [CrossRef]

98. Mangla, S.K.; Luthra, S.; Jakhar, S.; Gandhi, S.; Muduli, K.; Kumar, A. A step to clean energy—Sustainability in energy system management in an emerging economy context. J. Clean. Prod. 2020, 242, 118462. [CrossRef]

99. Mokarram, M.; Mokarram, M.J.; Gitizadeh, M.; Niknam, T.; Aghaei, J. A novel optimal placing of solar farms utilizing multicriteria decision-making (MCDA) and feature selection. J. Clean. Prod. 2020, 261, 121098. [CrossRef]

100. Moradi, S.; Yousefi, H.; Noorollahi, Y.; Rosso, D. Multi-criteria decision support system for wind farm site selection and sensitivity analysis: Case study of Alborz Province, Iran. Energy Strat. Rev. 2020, 29, 100478. [CrossRef]

101. Çolak, M.; Kaya, I. Multi-criteria evaluation of energy storage technologies based on hesitant fuzzy information: A case study for Turkey. J. Energy Storage 2020, 28, 101211. [CrossRef]

102. Adedeji, P.A.; Akinlabi, S.A.; Madushele, N.; Olatunji, O.O. Neuro-fuzzy resource forecast in site suitability assessment for wind and solar energy: A mini review. J. Clean. Prod. 2020, 269, 122104. [CrossRef]

103. Geng, S.; Lin, L.; Zhang, L.; Liu, X.; Huang, Z. Site selection framework of fishing photovoltaic hybrid project under intervalvalued intuitionistic fuzzy environment. J. Clean. Prod. 2020, 252, 119774. [CrossRef]

104. Alao, M.; Ayodele, T.; Ogunjuyigbe, A.; Popoola, O. Multi-criteria decision based waste to energy technology selection using entropy-weighted TOPSIS technique: The case study of Lagos, Nigeria. Energy 2020, 201, 117675. [CrossRef]

105. Pamucar, D.; Iordache, M.; Deveci, M.; Schitea, D.; Iordache, I. A new hybrid fuzzy multi-criteria decision methodology model for prioritizing the alternatives of the hydrogen bus development: A case study from Romania. Int. J. Hydrog. Energy 2021, 46, 29616-29637. [CrossRef]

106. Wu, Y.; Zhang, T.; Yi, L. An internal type-2 trapezoidal fuzzy sets-PROMETHEE-II based Investment decision framework of compressed air energy storage project in China under the perspective of different investors. J. Energy Storage 2020, 30, 101548. [CrossRef]

107. Wu, Y.; Tao, Y.; Zhang, B.; Wang, S.; Xu, C.; Zhou, J. A decision framework of offshore wind power station site selection using a PROMETHEE method under intuitionistic fuzzy environment: A case in China. Ocean Coast. Manag. 2020, 184, 105016. [CrossRef]

108. Cheng, F.; Lin, M.; Yuksel, S.; Dincer, H.; Kalkavan, H. A hybrid hesitant 2-tuple IVSF decision making approach to analyze PERT-Based critical paths of new service development process for renewable energy investment projects. IEEE Access 2021, 9, 3947-3969. [CrossRef]

109. Tarife, R.P.; Nakanishi, Y.; Bondaug, J.V.S.; Irosido, R.V.; Tahud, A.P.; Estoperez, N.R. Optimization of electric transmission line routing for a renewable energy based micro-grid system using geographic information system (GIS) spatial analysis. In Proceedings of the 2020 9th International Conference on Renewable Energy Research and Application (ICRERA), Glasgow, UK, 27-30 September 2020; pp. 215-220.

110. Feng, J. Wind farm site selection from the perspective of sustainability: A novel satisfaction degree-based fuzzy axiomatic design approach. Int. J. Energy Res. 2021, 45, 1097-1127. [CrossRef] 
111. Mrówczyńska, M.; Skiba, M.; Sztubecka, M.; Bazan-Krzywoszańska, A.; Kazak, J.; Gajownik, P. Scenarios as a tool supporting decisions in urban energy policy: The analysis using fuzzy logic, multi-criteria analysis and GIS tools. Renew. Sustain. Energy Rev. 2021, 137, 110598. [CrossRef]

112. Kumar, A.; Kothari, R.; Sahu, S.K.; Kundalwal, S.I. Selection of phase-change material for thermal management of electronic devices using multi-attribute decision-making technique. Int. J. Energy Res. 2021, 45, 2023-2042. [CrossRef]

113. Krishankumar, R.; Nimmagadda, S.S.; Rani, P.; Mishra, A.R.; Ravichandran, K.; Gandomi, A.H. Solving renewable energy source selection problems using a q-rung orthopair fuzzy-based integrated decision-making approach. J. Clean. Prod. 2021, $279,123329$. [CrossRef]

114. Liu, H.; Shen, W.; He, X.; Zeng, B.; Liu, Y.; Zeng, M.; Zhao, C. Multi-scenario comprehensive benefit evaluation model of a multi-energy micro-grid based on the matter-element extension model. Energy Sci. Eng. 2021, 9, 402-416. [CrossRef]

115. Ahmad, S.; Ouenniche, J.; Kolosz, B.W.; Greening, P.; Andresen, J.M.; Maroto-Valer, M.M.; Xu, B. A stakeholders' participatory approach to multi-criteria assessment of sustainable aviation fuels production pathways. Int. J. Prod. Econ. 2021, $238,108156$. [CrossRef]

116. Hashmi, N.; Jalil, S.A.; Javaid, S. Carbon footprint based multi-objective supplier selection problem with uncertain parameters and fuzzy linguistic preferences. Sustain. Oper. Comput. 2021, 2, 20-29. [CrossRef]

117. Fetanat, A.; Tayebi, M.; Mofid, H. Water-energy-food security nexus based selection of energy recovery from wastewater treatment technologies: An extended decision making framework under intuitionistic fuzzy environment. Sustain. Energy Technol. Assess. 2021, 43, 100937. [CrossRef]

118. Li, Y.-X.; Wu, Z.-X.; Dinçer, H.; Kalkavan, H.; Yüksel, S. Analyzing TRIZ-based strategic priorities of customer expectations for renewable energy investments with interval type-2 fuzzy modeling. Energy Rep. 2021, 7, 95-108. [CrossRef]

119. Adedeji, P.A.; Akinlabi, S.A.; Madushele, N.; Olatunji, O.O. Hybrid neurofuzzy wind power forecast and wind turbine location for embedded generation. Int. J. Energy Res. 2021, 45, 413-428. [CrossRef]

120. Malik, H.; Yadav, A.K. A novel hybrid approach based on relief algorithm and fuzzy reinforcement learning approach for predicting wind speed. Sustain. Energy Technol. Assess. 2021, 43, 100920. [CrossRef]

121. Gulzar, M.M.; Sibtain, D.; Murtaza, A.F.; Murawwat, S.; Saadi, M.; Jameel, A. Adaptive fuzzy based optimized proportionalintegral controller to mitigate the frequency oscillation of multi-area photovoltaic thermal system. Int. Trans. Electr. Energ Syst. 2021, 31, e12643. [CrossRef]

122. Kotb, K.M.; Elkadeem, M.; Khalil, A.; Imam, S.M.; Hamada, M.A.; Sharshir, S.W.; Dán, A. A fuzzy decision-making model for optimal design of solar, wind, diesel-based RO desalination integrating flow-battery and pumped-hydro storage: Case study in Baltim, Egypt. Energy Convers. Manag. 2021, 235, 113962. [CrossRef]

123. Lin, Z.; Liu, Y.; Xu, J.; Ma, J.; Liu, S.; Zhang, L.; Yu, M.; Jin, W.; Yang, L.; Lin, Z. Energy-saving rating of green Bed and Breakfast based on the fuzzy comprehensive evaluation. Energy Rep. 2021, 7, 197-203. [CrossRef]

124. Wang, W.; Tian, G.; Zhang, T.; Jabarullahg, N.H.; Li, F.; Fathollahi-Fard, A.M.; Wang, D.; Li, Z. Scheme selection of design for disassembly (DFD) based on sustainability: A novel hybrid of interval 2-tuple linguistic intuitionistic fuzzy numbers and regret theory. J. Clean. Prod. 2021, 281, 124724. [CrossRef]

125. Wang, R.; Li, X.; Li, C. Optimal selection of sustainable battery supplier for battery swapping station based on Triangular fuzzy entropy-MULTIMOORA method. J. Energy Storage 2021, 34, 102013. [CrossRef]

126. Mei, M.; Chen, Z. Evaluation and selection of sustainable hydrogen production technology with hybrid uncertain sustainability indicators based on rough-fuzzy BWM-DEA. Renew. Energy 2021, 165, 716-730. [CrossRef]

127. Yang, Z.; Chang, J. A multi-attribute decision-making-based site selection assessment algorithm for garbage disposal plant using interval q-rung orthopair fuzzy power Muirhead mean operator. Environ. Res. 2021, 193, 110385. [CrossRef]

128. Clauberg, A.P.C.; De Mello, R.; Simioni, F.J.; Sehnem, S. System for assessing the sustainability conditions of small hydro plants by fuzzy logic. Sustain. Dev. 2020, 29, 300-317. [CrossRef]

129. Yazır, D.; Şahin, B.; Yip, T.L. Selection of new design gas carriers by using fuzzy EVAMIX method. Asian J. Shipp. Logist. 2021, 37, 91-104. [CrossRef]

130. Sun, F.; Yu, J. Improved energy performance evaluating and ranking approach for office buildings using Simple-normalization, Entropy-based TOPSIS and K-means method. Energy Rep. 2021, 7, 1560-1570. [CrossRef]

131. Lo, H.-W.; Hsu, C.-C.; Chen, B.-C.; Liou, J.J. Building a grey-based multi-criteria decision-making model for offshore wind farm site selection. Sustain. Energy Technol. Assess. 2021, 43, 100935. [CrossRef]

132. Mostafaeipour, A.; Dehshiri, S.S.H.; Almutairi, K.; Taher, R.; Issakhov, A.; Techato, K. A thorough analysis of renewable hydrogen projects development in Uzbekistan using MCDM methods. Int. J. Hydrog. Energy 2021, 46, 31174-31190. [CrossRef]

133. Balezentis, T.; Siksnelyte-Butkiene, I.; Streimikiene, D. Stakeholder Involvement for sustainable energy development based on uncertain group decision making: Prioritizing the renewable energy heating technologies and the BWM-WASPAS-IN approach. Sustain. Cities Soc. 2021, 73, 103114. [CrossRef]

134. Ghouchani, M.; Taji, M.; Cheheltani, A.S.; Chehr, M.S. Developing a perspective on the use of renewable energy in Iran. Technol. Forecast. Soc. Chang. 2021, 172, 121049. [CrossRef]

135. Ullah, Z.; Elkadeem, M.; Kotb, K.M.; Taha, I.B.; Wang, S. Multi-criteria decision-making model for optimal planning of on/off grid hybrid solar, wind, hydro, biomass clean electricity supply. Renew. Energy 2021, 179, 885-910. [CrossRef] 
136. Ervural, B.C.; Zaim, S.; Demirel, O.F.; Aydin, Z.; Delen, D. An ANP and fuzzy TOPSIS-based SWOT analysis for Turkey's energy planning. Renew. Sustain. Energy Rev. 2018, 82, 1538-1550. [CrossRef]

137. Wang, C.-N.; Dang, T.-T.; Tibo, H.; Duong, D.-H. Assessing renewable energy production capabilities using DEA window and fuzzy TOPSIS model. Symmetry 2020, 13,1-20.

138. Liu, J.; Lv, J.; Dinçer, H.; Yüksel, S.; Karakuş, H. Selection of renewable energy alternatives for green blockchain investments: A hybrid IT2-based fuzzy modelling. Arch. Comput. Methods Eng. 2021, 28, 3687-3701. [CrossRef]

139. Gökgöz, F.; Yalçın, E. Investigating the Environmental and Economic Performances of Energy Sector in OECD Countries Via MCDM Approaches Bt-Sustaining Tomorrow; Ting, D.S.-K., Vasel-Be-Hagh, A., Eds.; Springer International Publishing: Cham, Switzerland, 2021; pp. 65-92.

140. Ulutas, A.; Karaca, C. Selection of Renewable energy sources for sustainable development and an economic model proposal for countries. In Emerging Economic Models for Global Sustainability and Social Development; Christiansen, B., Sysoeva, I., Udovikina, A., Ketova, A., Eds.; IGI Global: Hershey, PA, USA, 2019; pp. 65-83. [CrossRef]

141. Malemnganbi, R.; Shimray, B.A. A comprehensive multi criteria model to rank solar power plant sites using soft computing techniques. Des. Eng. 2021, 2021, 884-896.

142. Ecer, F. A consolidated MCDM framework for performance assessment of battery electric vehicles based on ranking strategies. Renew. Sustain. Energy Rev. 2021, 143, 110916. [CrossRef]

143. Ramos-Escudero, A.; García-Cascales, M.S.; Cuevas, J.M.; Sanner, B.; Urchueguía, J.F. Spatial analysis of indicators affecting the exploitation of shallow geothermal energy at European scale. Renew. Energy 2021, 167, 266-281. [CrossRef]

144. Gkeka-Serpetsidaki, P.; Tsoutsos, T. Sustainable site selection of offshore wind farms using GIS-based multi-criteria decision analysis and analytical hierarchy process. Case study: Island of Crete (Greece). Low Carbon Energy Technol. Sustain. Energy Syst. 2021, 7, 329-342. [CrossRef]

145. Kannan, D.; Moazzeni, S.; Darmian, S.M.; Afrasiabi, A. A hybrid approach based on MCDM methods and Monte Carlo simulation for sustainable evaluation of potential solar sites in east of Iran. J. Clean. Prod. 2021, 279, 122368. [CrossRef]

146. Abdel-Basset, M.; Gamal, A.; Chakrabortty, R.K.; Ryan, M.J. Evaluation approach for sustainable renewable energy systems under uncertain environment: A case study. Renew. Energy 2021, 168, 1073-1095. [CrossRef]

147. Xie, Y.; Zhou, Y.; Peng, Y.; Dincer, H.; Yuksel, S.; Xiang, P.A. An extended pythagorean fuzzy approach to group decisionmaking with incomplete preferences for analyzing balanced scorecard-based renewable energy investments. IEEE Access 2021, 9 , 43020-43035. [CrossRef]

148. Saraswat, S.; Digalwar, A.K. Evaluation of energy alternatives for sustainable development of energy sector in India: An integrated Shannon's entropy fuzzy multi-criteria decision approach. Renew. Energy 2021, 171, 58-74. [CrossRef]

149. Pan, X.; Wang, Y. Evaluation of renewable energy sources in China using an interval type-2 fuzzy large-scale group risk evaluation method. Appl. Soft Comput. 2021, 108, 107458. [CrossRef]

150. Karaaslan, A.; Adar, T.; Delice, E.K. Regional evaluation of renewable energy sources in Turkey by new integrated AHP-MARCOS methodology: A real application. Int. J. Sustain. Energy 2021, 1-23. [CrossRef]

151. Dang, R.; Li, X.; Li, C.; Xu, C. A MCDM framework for site selection of island photovoltaic charging station based on new criteria identification and a hybrid fuzzy approach. Sustain. Cities Soc. 2021, 74, 103230. [CrossRef]

152. Qazi, A.; Bhowmik, C.; Hussain, F.; Yang, S.; Naseem, U.; Adebayo, A.-A.; Gumaei, A.; Al-Rakhami, M. Analyzing the public opinion as a guide for renewable-energy status in Malaysia: A case study. IEEE Trans. Eng. Manag. 2021, 1-15. [CrossRef]

153. Karatop, B.; Taşkan, B.; Adar, E.; Kubat, C. Decision analysis related to the renewable energy investments in Turkey based on a Fuzzy AHP-EDAS-Fuzzy FMEA approach. Comput. Ind. Eng. 2021, 151, 106958. [CrossRef]

154. Günen, M.A. Determination of the suitable sites for constructing solar photovoltaic (PV) power plants in Kayseri, Turkey using GIS-based ranking and AHP methods. Environ. Sci. Pollut. Res. 2021, 1-16. [CrossRef]

155. Akçay, M.; Atak, M. Optimal site selection for a solar power plant in Turkey using a hybrid AHP-TOPSIS method. Celal Bayar Üniversitesi Fen Bilimleri Dergisi 2018, 14, 413-420. [CrossRef]

156. Dominguez, C.; Orehounig, K.; Carmeliet, J. Understanding the path towards a clean energy transition and post-electrification patterns of rural households. Energy Sustain. Dev. 2021, 61, 46-64. [CrossRef]

157. Lin, R.; Ren, J. Overview of Multi-Criteria Decision Analysis and Its Applications on Energy Systems BT-Energy Systems Evaluation; Ren, J., Ed.; Springer International Publishing: Cham, Switzerland, 2021; Volume 2, pp. 1-26.

158. Shorabeh, S.N.; Argany, M.; Rabiei, J.; Firozjaei, H.K.; Nematollahi, O. Potential assessment of multi-renewable energy farms establishment using spatial multi-criteria decision analysis: A case study and mapping in Iran. J. Clean. Prod. 2021, 295, 126318. [CrossRef]

159. Lopes, J.; Bresciani, A.; Carvalho, K.; Kulay, L.; Alves, R. Multi-criteria decision approach to select carbon dioxide and hydrogen sources as potential raw materials for the production of chemicals. Renew. Sustain. Energy Rev. 2021, 151, 111542. [CrossRef]

160. Rahoma, I.; Obeidat, F. Future energy mix mapping for jordan using multi criteria decision analysis. In Proceedings of the 12th International Renewable Engineering Conference (IREC), Amman, Jordan, 14-15 April 2021; pp. 1-5.

161. Ajanaku, B.A.; Strager, M.P.; Collins, A.R. GIS-based multi-criteria decision analysis of utility-scale wind farm site suitability in West Virginia. GeoJournal 2021, 1-23. [CrossRef]

162. Zambrano-Asanza, S.; Quiros-Tortos, J.; Franco, J.F. Optimal site selection for photovoltaic power plants using a GIS-based multi-criteria decision making and spatial overlay with electric load. Renew. Sustain. Energy Rev. 2021, 143, 110853. [CrossRef] 
163. Ulewicz, R.; Siwiec, D.; Pacana, A.; Tutak, M.; Brodny, J. Multi-Criteria method for the selection of renewable energy sources in the polish industrial sector. Energies 2021, 14, 2386. [CrossRef]

164. Crivellari, A.; Moreno, V.C.; Cozzani, V.; Dincer, I. Multi-criteria sustainability assessment of potential methanol production processes. J. Clean. Prod. 2021, 293, 126226. [CrossRef]

165. Babatunde, O.; Denwigwe, I.; Oyebode, O.; Ighravwe, D.; Ohiaeri, A.; Babatunde, D. Assessing the use of hybrid renewable energy system with battery storage for power generation in a University in Nigeria. Environ. Sci. Pollut. Res. 2021, 1-20. [CrossRef]

166. Prieto-Amparán, J.; Pinedo-Alvarez, A.; Morales-Nieto, C.; Valles-Aragón, M.; Álvarez-Holguín, A.; Villarreal-Guerrero, F. A regional GIS-assisted multi-criteria evaluation of site-suitability for the development of solar farms. Land 2021, 10, 217. [CrossRef]

167. Tercan, E.; Eymen, A.; Urfalı, T.; Saracoglu, B.O. A sustainable framework for spatial planning of photovoltaic solar farms using GIS and multi-criteria assessment approach in Central Anatolia, Turkey. Land Use Policy 2021, 102, 105272. [CrossRef]

168. Hwang, H.; Kim, S.; García Álvaro, G.; Kim, J. Global sensitivity analysis for assessing the economic feasibility of renewable energy systems for an off-grid electrified city. Energy 2021, 216, 119218. [CrossRef]

169. Naegler, T.; Becker, L.; Buchgeister, J.; Hauser, W.; Hottenroth, H.; Junne, T.; Lehr, U.; Scheel, O.; Schmidt-Scheele, R.; Simon, S.; et al. Integrated Multidimensional sustainability assessment of energy system transformation pathways. Sustainability 2021, 13, 5217. [CrossRef]

170. Sipa, M.; Gorzeń-Mitka, I. Assessment of the progress towards the management of renewable energy consumption in the innovativeness context-A country approach. Energies 2021, 14, 5064. [CrossRef]

171. Lucheroni, C.; Mari, C. Internal hedging of intermittent renewable power generation and optimal portfolio selection. Ann. Oper. Res. 2019, 299, 873-893. [CrossRef]

172. Castangia, M.; Aliberti, A.; Bottaccioli, L.; Macii, E.; Patti, E. A compound of feature selection techniques to improve solar radiation forecasting. Expert Syst. Appl. 2021, 178, 114979. [CrossRef]

173. Bertolino, A.; Fürst, M.; Stagni, A.; Frassoldati, A.; Pelucchi, M.; Cavallotti, C.; Faravelli, T.; Parente, A. An evolutionary, data-driven approach for mechanism optimization: Theory and application to ammonia combustion. Combust. Flame 2021, 229, 111366. [CrossRef]

174. Derbeli, M.; Napole, C.; Barambones, O. Machine learning approach for modeling and control of a commercial heliocentris FC50 PEM fuel cell system. Mathematics 2021, 9, 2068. [CrossRef]

175. Idris, M.N.M.; Hashim, H.; Leduc, S.; Yowargana, P.; Kraxner, F.; Woon, K.S. Deploying Bioenergy for decarbonizing malaysian energy sectors and alleviating renewable energy poverty. Energy 2021, 232, 120967. [CrossRef]

176. Alam, S.; Ahmad, M.; Othman, A.; Shaari, Z.; Masukujjaman, M. Factors affecting photovoltaic solar technology usage intention among households in Malaysia: Model integration and empirical validation. Sustainability 2021, 13, 1773. [CrossRef]

177. Alberizzi, J.C.; Frigola, J.M.; Rossi, M.; Renzi, M. Optimal sizing of a hybrid renewable energy system: Importance of data selection with highly variable renewable energy sources. Energy Convers. Manag. 2020, 223, 113303. [CrossRef]

178. Hernandez, E.M.; Guerras, L.S.; Martín, M. Optimal technology selection for the biogas upgrading to biomethane. J. Clean. Prod. 2020, 267, 122032. [CrossRef]

179. Oregi, X.; Hernández, R.J.; Hernandez, P. Environmental and economic prioritization of building energy refurbishment strategies with life-cycle approach. Sustainability 2020, 12, 3914. [CrossRef]

180. Supriya, M.; Sangeeta, K.; Patra, G.K. Comparison of AHP based and Fuzzy based mechanisms for ranking Cloud Computing services. In Proceedings of the International Conference on Computer, Control, Informatics and Its Applications: Emerging Trends in the Era of Internet of Things, IC3INA, Bandung, Indonesia, 5-7 October 2015; pp. 175-180. [CrossRef]

181. Dinesh, S.; Rejikumar, G.; Sisodia, G.S. An empirical investigation into carpooling behaviour for sustainability. Transp. Res. Part F. Traffic Psychol. Behav. 2021, 77, 181-196. [CrossRef]

182. Rani, P.; Mishra, A.R.; Krishankumar, R.; Ravichandran, K.; Kar, S. Multi-criteria food waste treatment method selection using single-valued neutrosophic-CRITIC-MULTIMOORA framework. Appl. Soft Comput. 2021, 111, 107657. [CrossRef]

183. Rani, P.; Ali, J.; Krishankumar, R.; Mishra, A.; Cavallaro, F.; Ravichandran, K. An integrated single-valued neutrosophic combined resource selection problem. Energies 2021, 14, 4594. [CrossRef] 